\title{
Spike-frequency dependent coregulation of multiple ionic conductances in fast-spiking cells forces a metabolic tradeoff
}

Yue Ban ${ }^{1,2 *}$, Rosalie Maltby ${ }^{1}$, and Michael R. Markham ${ }^{1,2}$

${ }^{1}$ Department of Biology, University of Oklahoma, Norman, OK 73019, USA

${ }^{2}$ Cellular \& Behavioral Neurobiology Graduate Program, University of Oklahoma, Norman, OK 73019, USA

*Corresponding author

University of Oklahoma

Biology Department

730 Van Vleet Oval, RH410

Norman, OK 73019

Email: yueban610@gmail.com

Pages: $\quad 61$

Word count: 13710 


\section{Coregulation of ionic conductances - 2}

\section{ABSTRACT}

High-frequency action potentials (APs) allow rapid information acquisition and

3 processing in neural systems, but create biophysical and metabolic challenges for excitable cells.

4 The electric fish Eigenmannia virescens images its world and communicates with high-

5 frequency (200-600 Hz) electric organ discharges (EODs) produced by synchronized APs

6 generated at the same frequency in the electric organ cells (electrocytes). We cloned three

7 previously unidentified $\mathrm{Na}^{+}$-activated $\mathrm{K}^{+}$channel isoforms from electroctyes (eSlack1, eSlack2,

8 and eSlick1). In electrocytes, mRNA transcript levels of the rapidly-activating eSlick, but not the

9 slower eSlack1 or eSlack2, correlated with EOD frequency across individuals. In addition,

10 transcript levels of an inward-rectifier $\mathrm{K}^{+}$channel, a voltage-gated $\mathrm{Na}^{+}$channel, and $\mathrm{Na}^{+}, \mathrm{K}^{+}-$

11 ATPases also correlated with EOD frequency while a second $\mathrm{Na}^{+}$channel isoform did not.

12 Computational simulations showed that maintaining electrocyte AP waveform integrity as firing

13 rates increase requires scaling conductances in accordance with these mRNA expression

14 correlations, causing AP metabolic costs to increase exponentially. 


\section{Coregulation of ionic conductances - 3}

\section{INTRODUCTION}

Organisms expend precious metabolic energy to acquire, process, and store information.

Action potentials (APs) are central to these processes because they are a fundamental unit of information in nervous systems. As a result, the rules that govern these energy-information tradeoffs are often revealed in the biophysical mechanisms of AP generation $[1,2]$. APs in excitable cells are initiated by depolarizing inward $\mathrm{Na}^{+}$currents and terminated by repolarizing outward $\mathrm{K}^{+}$currents. Each AP incurs a metabolic cost when the $\mathrm{Na}^{+}, \mathrm{K}^{+}$-ATPases hydrolyze ATP to restore the transmembrane $\mathrm{Na}^{+}$and $\mathrm{K}^{+}$gradients after each AP. The kinetics and densities of the $\mathrm{Na}^{+}$and $\mathrm{K}^{+}$ion channels that generate these APs determine the waveform of each individual $\mathrm{AP}$, the maximum AP firing rate and, ultimately, the metabolic costs of AP generation.

Sustaining high AP firing frequencies supports rapid information acquisition and processing [35], but presents a significant metabolic challenge for two reasons. First, the very feature of high firing rates imposes metabolic costs by virtue of more APs per unit time. Second, maintaining high firing rates requires very brief APs, and the generation of brief APs often requires the metabolically inefficient overlap of depolarizing $\mathrm{Na}^{+}$currents and repolarizing $\mathrm{K}^{+}$currents [6].

The freshwater weakly electric fish Eigenmannia virescens generates high-frequency electric organ discharges (EODs) to image their world and communicate in darkness (Fig. 1) [7]. E. virescens has a considerable animal-to-animal variability in EOD frequency (EODf) which is set by a medullary pacemaker nucleus, with each fish maintaining a relatively fixed frequency in the range of 200-600 Hz [8]. Early studies on the behavior of E. virescens suggested that EODf conveys information about individual identity, gender and dominance rank [7,9]. These highfrequency EODs confer two major advantages by providing fast sensory sampling rates and 


\section{Coregulation of ionic conductances - 4}

37 shifting the signal energy away from low frequencies that are detectable by electroreceptive predators [10], but high-frequency EODs also incur staggering metabolic costs [11].

The EOD is produced by more than 1000 electric organ cells (electrocytes) that generate near simultaneous APs at the EOD frequency $(200-600 \mathrm{~Hz})$, approximately the same frequency range as the maximum sustained firing rates for fast-spiking mammalian cortical neurons [12] and brainstem auditory neurons [13]. However, electrocytes maintain these high frequencies unremittingly throughout the lifespan, whereas central neurons sustain such high firing rates only

44 for brief periods. Further, in addition to the biophysical and metabolic challenges associated with maintaining constant high-frequency APs, the resulting metabolic costs are amplified in $E$. virescens electrocytes because electrocyte ionic currents can exceed $10 \mu \mathrm{A}$ during each AP, with corresponding entry of approximately $2 \times 10^{10} \mathrm{Na}^{+}$ions into the cell during each AP $[11,14]$.

48 These large ionic currents create extreme metabolic demands because one ATP must be hydrolyzed by the $\mathrm{Na}^{+}, \mathrm{K}^{+}$-ATPase for every three $\mathrm{Na}^{+}$ions returned to the extracellular space. High firing rates also create extreme demand for rapid charge translocation by the $\mathrm{Na}^{+}, \mathrm{K}^{+}-$ to as little as $0.8 \mathrm{~ms}$ across the EODf range of $200-600 \mathrm{~Hz}$.

Here we investigated the ionic mechanisms associated with high-frequency APs in $E$. virescens electrocytes and the associated demands on $\mathrm{Na}^{+}, \mathrm{K}^{+}$-ATPase activity. Electrocytes are

56 with the activation of cholinergic receptors and $\mathrm{Na}_{\mathrm{v}}$ channels on the innervated posterior

57 membrane to allow the influx of $\mathrm{Na}^{+}$(Fig. 1). Electrocytes in E. virescens terminate APs with

$58 \mathrm{Na}^{+}$-activated $\mathrm{K}^{+}\left(\mathrm{K}_{\mathrm{Na}}\right)$ channels rather than the voltage gated $\mathrm{K}^{+}(\mathrm{Kv})$ channels that terminate 
Numerous studies have suggested that the density and kinetic properties of $\mathrm{K}^{+}$channels

61 in the plasma membrane are key determinants of an excitable cell's functional capacity [18-23].

62 Therefore, we cloned the cDNAs encoding the $\mathrm{K}_{\mathrm{Na}}$ channels in E. virescens $\mathrm{EOs}$ and identified

63 three different types of $\mathrm{K}_{\mathrm{Na}}$ channel subunits expressed in electrocytes. Two of these channels,

64 eSlack1 and eSlack2, closely resemble $\mathrm{K}_{\mathrm{Na}}$ channels encoded by the Slack gene in mammalian

65 systems; and the third channel, eSlick, shares the highest homology to the Slick channel in rat.

66 By expressing fluorescent protein tagged $\mathrm{K}_{\mathrm{Na}}$ channel subunits in electrocytes, we showed that

67 all three $\mathrm{K}_{\mathrm{Na}}$ channels are expressed on the cell's anterior region, separated by $>1 \mathrm{~mm}$ from the

$68 \mathrm{Na}_{\mathrm{v}}$ channels which are restricted to the posterior membrane.

We also examined the functional differences among the three $\mathrm{K}_{\mathrm{Na}}$ channels by expressing

71 activated much more rapidly than eSlack1 currents. To explore which conductances play key

72 roles in determining the firing frequency of electrocytes, we used qRT-PCR to measure the

73 mRNA levels of genes encoding ion channels and $\mathrm{Na}^{+} / \mathrm{K}^{+}$ATPases in EO from fish with

74 different EODf. The transcription levels of eSlick, Nav1.4a, Kir6.2 and $\mathrm{Na}^{+} / \mathrm{K}^{+}$ATPase increase

75 with EODf, while transcription levels of eSlack1, eSlack2, Nav1.4b did not correlate with EODf.

In computational simulations of electrocytes stimulated at a broad range of EODfs, we

77 found that maintaining AP integrity across firing rates required scaling ionic conductances in

78 accordance with our experimentally derived mRNA expression correlations. These simulations

79 also revealed that AP metabolic costs and the rate of required charge translocation by the

$80 \mathrm{Na}^{+}, \mathrm{K}^{+}$-ATPases increased exponentially with higher frequencies. 
bioRxiv preprint doi: https://doi.org/10.1101/2021.03.08.434486; this version posted March 9, 2021. The copyright holder for this preprint (which was not certified by peer review) is the author/funder, who has granted bioRxiv a license to display the preprint in perpetuity. It is made available under aCC-BY-NC-ND 4.0 International license.

\section{Coregulation of ionic conductances - 6}
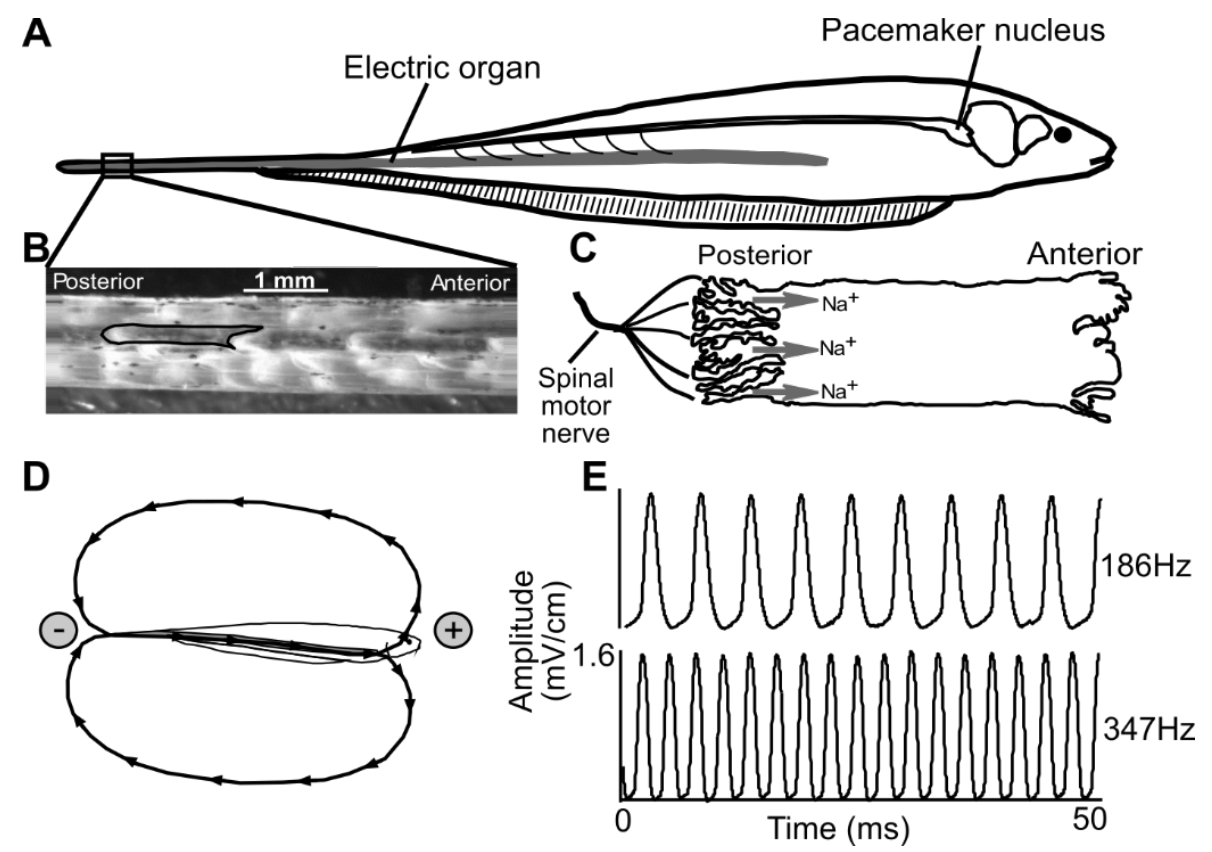

Fig.1. EOD generation in $E$. virescens. $A$ : The EO runs longitudinally along the fish body and extends into the caudal tail filament. $B$ : A section from the tail with skin removed to expose the EO. A single electrocyte is outlined in black. $C$ : Schematic of an electrocyte. Electrocytes are highly polarized cells approximately 1.5 $\mathrm{mm}$ in anterior-posterior length and $0.6 \mathrm{~mm}$ in diameter. Electrocyte APs are controlled by the medullary pacemaker nucleus via spinal motor neurons innervating on the posterior membrane of each electrocyte. The cell's innervated posterior face is deeply invaginated and occupied by cholinergic receptors and voltage gated $\mathrm{Na}^{+}\left(\mathrm{Na}_{\mathrm{v}}\right)$ channels. The activation of cholinergic synapses causes an inward $\mathrm{Na}^{+}$current. $D$ : The $\mathrm{Na}^{+}$current moves toward the head, and followed by a return path from head to tail in the surrounding water. $E$ : The EOD waveforms recorded from fish with high and low EOD frequency. Panels A-D were modified from Ban et al., 2015.

\section{RESULTS}

Molecular identities of $\mathrm{K}_{\mathrm{Na}}$ channels in $E$. virescens electrocytes

Mammalian $\mathrm{K}_{\mathrm{Na}}$ channels are encoded by two highly similar paralog genes, Slo2.1 (Slick, kcnt2) and Slo2.2(Slack, kcnt1) belonging to the Slo gene family [24, 25]. In E. virescens EOs, analysis (Fig. 2A) of channels in the SLO family show that two cloned cDNAs have the 
91 respectively, which share $68.6 \%$ homology. Amino acid differences between the two Slack

92 proteins were dispersed along the entire sequence, suggesting they are not likely generated by

93 RNA alternative splicing. Given the evidence that duplication of voltage gated sodium and

94 potassium channel genes has occurred in multiple gymnotiform species $[21,26]$, gene

95 duplication is more likely the mechanism giving rise to the two Slack transcript variants in $E$.

96 virescens. We designated the duplicated Slack genes in E. virescens as eSlack1 (ORF: $3495 \mathrm{nt})$

97 and eSlack2 (ORF: $3093 \mathrm{nt}$ ). Therefore, E. virescens EOs express three different $\mathrm{K}_{\mathrm{Na}}$ channel

98 subunits, encoded by both Slack and Slick genes.

In all but one genus of weakly electric fish, electric organs (EOs) are derived from

100 skeletal muscle [27]. With the development and maturation of EOs, electrocytes eliminate the

101 coupling between contraction and excitability $[28,29]$. Due to the myogenic origin of EO tissue,

102 we examined the expression pattern of eSlack1, eSlack2, and eSlick in E. virescens muscle and

103 EO by reverse transcription PCR and found that eSlack1 and eSlack2 are expressed in both EO

104 and muscle, whereas Slick is expressed only in the EO (Fig. 2B). 

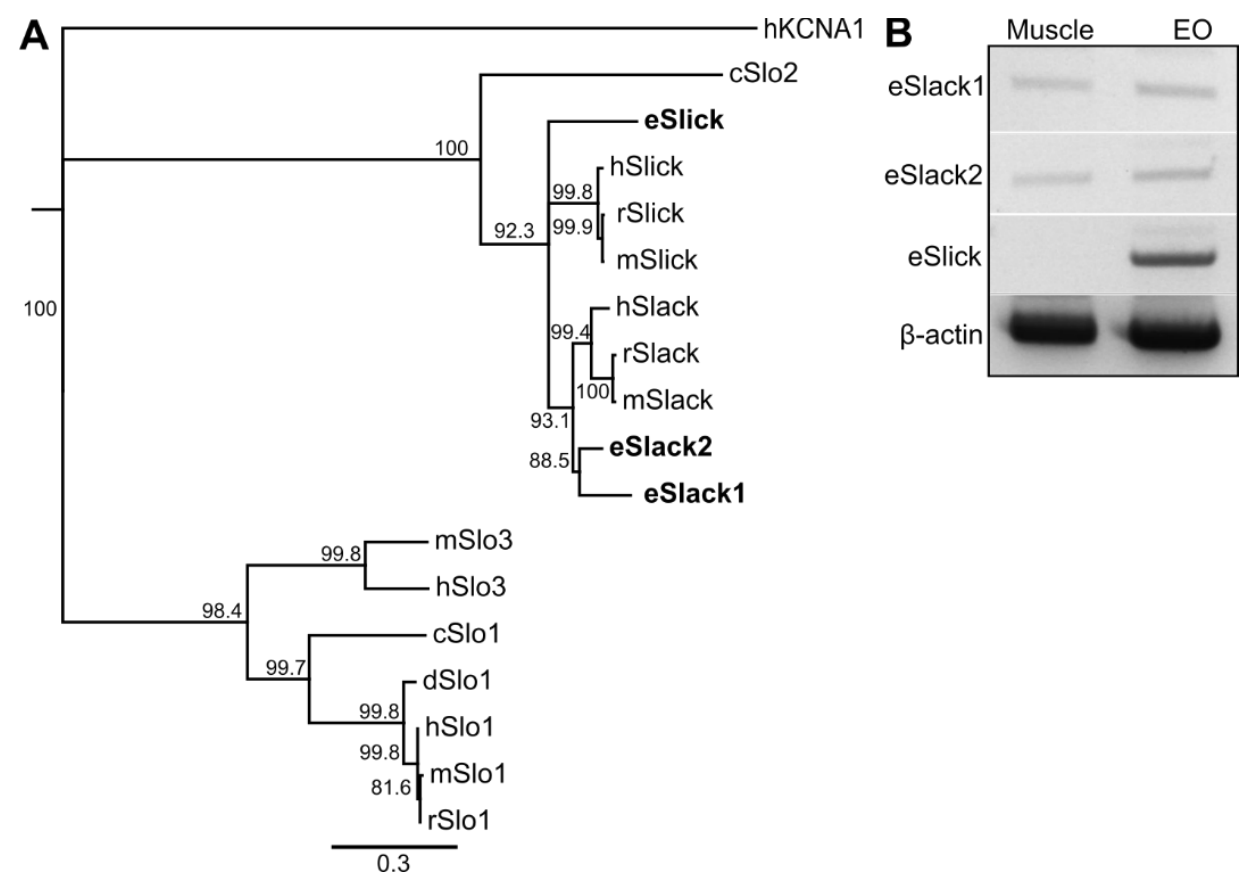

Fig. 2. Molecular identities of $\boldsymbol{E}$. virescens $\mathbf{K}_{\mathrm{Na}}$ channel genes. $A$ : A rooted neighbor-joining phylogenetic tree for the high conductance potassium channels in the SLO family. The family of SLO channels includes Slo1 (the "big" potassium (BK) $\mathrm{K}_{\mathrm{Ca}}$ channel), Slo2.1 (the Slick $\mathrm{K}_{\mathrm{Na}}$ channel), Slo2.2 (the Slack $\mathrm{K}_{\mathrm{Na}}$ channel), and Slo3 (the large conductance $\mathrm{pH}-$ sensitive $\mathrm{K}^{+}$channel). Human Kv1.1 was used as the outgroup. (h: Homo sapiens; r: Rattus norvegicus; m: Mus musculus; d: Danio rerio; c: Caenorhabditis elegans; e: Eigenmannia virescens). B: Expression pattern of E. virescens $\mathrm{K}_{\mathrm{Na}}$ channels in muscle and EO. eSlack1 and eSlack2 were amplified from the cDNA of both muscle and EO, whereas eSlick was only amplified from EO cDNA. Primers and amplicon sizes are listed in Table 1.

Sequence and Structure of $E$. virescens $\mathrm{K}_{\mathrm{Na}}$ Channels

The E. virescens eSlack1 and eSlack2 channel subunits share $74.3 \%$ and $70.8 \%$

111 spanning domains (S1-S6) with a pore-forming loop between S5 and S6, and an extensive

112 cytoplasmic C-terminal region (Fig. 3) [24, 31-33]. Slack channels are activated by intracellular

$113 \mathrm{Na}^{+}$ions, and the sensitivity of these channels to $\mathrm{Na}^{+}$is determined by the presence of a $\mathrm{Na}^{+}$

114 coordination motif in the second Regulator of $\mathrm{K}^{+}$conduction $(\mathrm{RCK})$ domain. This motif contains 
115 six amino acids in rat Slack subunits ( $\underline{\mathrm{DNKPDH}})$, with aspartic acid (D) and histidine (H) in the

116 beginning and ending position [34]. In the homologous position, E. virescens Slack-1 and Slack-

1172 subunits have the sequence $\underline{\mathrm{D} N Q P D D} \underline{\mathrm{H}}$ and $\underline{\mathrm{D} N P P D N} \underline{\mathrm{H}}$ respectively, making them putative

$118 \mathrm{Na}^{+}$binding sites (Fig. 3A). There is great divergence between E. virescens Slack-1 and Slack-2

119 in the N- and C- terminus. eSlack2 has a C-terminal tail approximately 100 amino acids shorter

120 than eSlack1 and all other identified Slack and Slick subunits in mammals (Fig. 2A). The N-

121 terminus is where amino acid differences are most frequently found between eSlack1 and

122 eSlack2. The N-terminus of eSlack2 is highly similar to that of mouse and rat Slack-A. In

123 mammals, RNA alternative splicing gives rise to three Slack transcripts, Slack-A, Slack-B and

124 Slack-M, which are regulated by alternative promoters and differ in the N-terminal residues [30].

125 eSlack1 has a unique N-terminus which is not similar to any known mammalian Slack isoforms

126 (Fig. 3). 
bioRxiv preprint doi: https://doi.org/10.1101/2021.03.08.434486; this version posted March 9, 2021. The copyright holder for this preprint (which was not certified by peer review) is the author/funder, who has granted bioRxiv a license to display the preprint in perpetuity. It is made available under aCC-BY-NC-ND 4.0 International license.

Coregulation of ionic conductances - 10

S1

eSlack1 -METKSAVPSWVN - PAVVTWRLDSFGSEAGQRVHVEFYVNENTFKERLKLFFIKNQRSSLRIRIFNFCLKVLTCVLYIIRVMTDNPAQLRKACMK - - - - - - - - 93 eSlack2 MADVDSEVPPLPPRYRFRDLLLGDQSFQNDDRVQVEFYVNENTFKERLKLFFIKNQRSSLRIRLFNLSLKLLTCLLYILRVSLDDPTTQVSCARKHCVNVTDALC 105 eSlick MVNAENEVPPLPQNYRFGDLFFGDTWQNDDKVQVELCTNENTLKERLKLFFIKNQSSSLRIRLFYFSLKLLSCVLYICRVLKESPEEHTCWNRTDQNYTLFKID 105 ISICK MNAENEVPPLPQNYRF rSlack MNDLDTEVLPLPPRYRFRDLLLGDQTFPNDDRVQVEFYVNENTFKERLKLFFIKNQRSSLRIRLFNFSLKLLTCLLYIVRVLLDNPDQGIGCWGCTKYN----- 99

rSlick MVDLESEVPPLPPRYRFRDLLLGDQGWQNDDRVQVEFYMNENTFKERLKLFFIKNQRSSLRIRLFNFSLKLLSCLLYIIRVLLEKPSQGN S4 S3

eSlack1 - - - CNSTSPSDE INWELIFWVDRKTPVWAIOVILASISFMEAMLITYLSYKGNIWEQIFQVTFLLEMLNTVPFIITIFWPTLRNLFIPVFLNCWLAKHALESMI

eSlack2 SKICANQTADPTQINWELIFWVSRKTPVWAIQVTVALISFLEAMLLTYLSYKGNIWEQIFQISYILEMINTVPFIITIFRPTWRNIFVPVFLNCWLAKSALENMI eSlick CWNRTDQNYTLFGIDWTPI IWVERDIILWALQVVVAVICLCQTILLTYLSYKRNIWEQIRRIKFVLEIINTVPFLITVMHFRLQNLFIPVFLNCWLAKHTLENMI 210 rSlack - - - YTFNGSSSEFHWAPILWVERKMALWVIQVIVATISFLETMLLIYLSYKGNIWEQIFHVSFVLEMINTLPFIITVFWPPLRNLFIPVFLNCWLAKHALENMI 200 rSlick -....... DWSHIFWVNRSLPLWGLQVSVALISLFETILLGYLSYKGNIWEQILRVPFILEIINAVPFIISIFWPTLRNLFVPVFLNCWLAKHALENMI S5

PORE

S6

ESlack1 NDLHRAIQRTHSAMFNQVLILICTLLCLVFTGTCGIQHLERAGGNSLSLFNSLYFCIVTFSTVGFGDVTPQIWPSQLLVVVMICVALVVLPLQFEELIYLWMERQ 299 eSlack2 NDLHRAIQRTHSAMFNQVLILICTLLCLVFTGACGIQHLERAGKN-LSLFDSLYFCIVTFSTVGYGDVTPRIWPSQLLVVIMICVALVVLPLQFEELAYLWMERQ 314 eSlick NDFHRAIQRTQSAMFNQVLILISTLFCLIFTCICGIHHLERAGQK-LSFFDSIYFCIVTFSTVGYGDVYPQIWPSKLLVVIMIFVALVVLPAQFEQLAYLWMERQ 314 rSlack NDFHRAILRTQSAMFNOVLILFCTLLCLVFTGTCGIQHLERAGGN - LNLLTSFYFCIVTFSTVGFGDVTPKIWPSQLLVVILICVTLVVLPLQFEELVYLWMERO rSlick NDLHRAIQRTQSAMFNQVLILISTLLCIFTCICGIQHLERIGKK-LNLFDSLYFCIVTFSTVGFGDVTPETWSSKLFVVAMICVALVVLPIQFEQLAYLWERQ

ESlack1 KSGGNYSRHRAQTEKHAVLCVSSLKIDLLMDFLNEFYAHPRTQDYYVVILCPCEADSQVRRVLQIPLWSQRVIYLQGSVLKNQDLLRAKMDDAEACFILSSRNEA eSlack2 KSGGNYSRHRAQTEKHVVLCVSSLKIDLLMDFLNEFYAHPRLQDYYVVILCPTEMDIQVRRVLQIPLWSQRVIYLQGSALKDQDLMRAKMDDAEACFILSSRNEV eSlick KSGGNYSQHRAETEKHVVLCVSSLKIELLLDFLNEFYAHPTLQDHCVVILCPTEMDAQVRRVLQIPMWTQRVIYLQGSALKDLDLFRSKLDNAEACFILSSRCEL

$\begin{aligned} \text { rSlack } & \text { KSGGNYSRHRARTEKHVVLCVSSLKIDLLMDFLNEFYAHPRLQDYYVVILCPSEMDVQVRRVLQIPLWSQRVIYLQGSALKDQDLMRAKMDNGEACFILSSRNEV } \\ \text { rSlick } & \text { KSGGNYSRHRAQTEKHVVLCVSSLKIDLLMDFLNEFYAHPRLQDYYVVILCPTEMDVQVRRVLQIPMWSQRVIYLQGSALKDQDLLRAKMDNAEACFILSSRCEV }\end{aligned}$

eSlack1 DRMAADHQTILRAWAVKDFAPNCPLYVQILKPENKFHVKFADHVVCEEEFKYALLALNCLCPATSTLVTLLVHTSRG-- - - - - QEGQQSPEQWQRMYGRCSGNE eSlack2 DRTAADHQTILRAWAVKDFAPNCPLYVQILKPENKFHVKFADHVVCEEEFKYAMLALNCVCPATSTLVTLLVHTSRG- - - - - Q QEGQMSPEQWQRTYGRCSGNE eSlick DRTAADHQTILRAWAVNDFAPNCPLYVQILKPENKFHVKFADHVVCEEEFKYALLALNCICPATSTLITLLVRTSEG-- - - - LEGQQSPEQWHRTYGKCSGN rSlack DRTAADHQTILRAWAVKDFAPNCPLYVQILKPENKFHVKFADHVVCEEECKYAMLALNCICPATSTLITLLVHTSRG-- - - QEGQESPEQWQRMYGRCSGN rSlick DRTSSDHQTILRAWAVKDFAPNCPLYVQILKPENKFHIKFADHVVCEEEFKYAMLALNCICPATSTLITLLVHTSRGQCVCLCCREGQQSPEQWQKTYGRCSGNE

eSlack1 VYHISLSDSMFFREYEKKSFTYAAFHAHKKYGVCLIGIKREDIKSILLNPGPRHIMAASDTCYYINITKEENSAFTVRQEAHQG-KGR--CDILNSPSGLPVHSI eSlack2 VYHIRLVDSKFFGEYDGKSFTYASFHAHKKYGVCLIGIKREDNKSILLNPGPRHIMAATDTCYYINITKEENSAFIFKQEEKHS-KGLPVTGLYDAPSRLPVQSI 621 eSlick VYNIILKDSIFFSEYEGKSFTYASFHTHKKYGVCLIGVRRKDSKNILLNPGHRYIMNSSDMCFYINITKEEDSAFKSKGERCKR - - - - - - - - SFRMRLPVRNI 612 rSlack VYHIRMGDSKFFREYEGKSFTYAAFHAHKKYGVCLIGLKREENKSILLNPGPRHILAASDTCFYINITKEENSAFIFKQEEKQNRRGLAGQALYEGPSRLPVHSI 612 rSlick VYHIVLEESTFFAEYEGKSFTYASFHAHKKFGVCLVGVRREDNKNILLNPGPRYIMNASDICFYINITKEENSAFKNQDQQRKSNVSR - - -SFYHGPSRLPVHSI

eSlack1 ITSMGTVAMDFQNTSP- - - - - TGDMAKLALPTE-NGAGSRRPSIAPVLEIADSASLLPCDLLSDQSEDEAAHSDEEVSSTYECVKGYPPNSPYIGSSPTLCHLLL 703 ESlack2 IASMGTVAIDLQNTEP-...-ATDSGKLAPPTE-NGAGSRRPSIAPVLELADTSSILPCDLLADPSEDETNQSDEEGVPAPDYVKGYPPNSPYIGSSPTLCHLLQ 720 eSlick VASVGTVALDLQDTSGK----SSWSASLSVPDEPAKAESRRPSIAPVLEVPTTPQLQGYAATSELPKDGTVQSLDDQFS-DRCIMGYPPNLPYIGSLQTLCHLLR 712 rSlack IASMVAMDLQNTDCRPSQGGSGGGGGKLTLPTE-NGSGSRRPS IAPVLELADSSALLPCDLLSDQSEDEVTPSDDEGLSVVEYVKGYPPNSPYIGSSPTLCHLLP 716 rSlick IASMGTVAIDLQDTSCR----AASGPTLALPSE-GGKELRRPSIAPVLEVADTSSIQTCDLLSDQSEDETTP-DEETSSNLEYAKGYPPYSPYIGSSPTFCHLLQ 696

eSlack1 QKAAFCCLRLDQACEHVSFEDAKAYGFQNKLIIVSAETAGNGLYNFIVPLRAYYRPRRELNPIVLLLDNQPDDHFLEAISCFPMVYYMVGTIDNLDSLLQCGILY 808 eSlack2 EKAPFCCLRLDKGCRHNSFEDAKAYGFKNKLIIVSAEMAGNGLYNFIVPLRAYYRPRKELNPIVLLLDNPPDNHFLEAICCFPMVYYMAGTIDNLDNLLQCGIIY 825 eSlick EKLPYCCLQLDKSCVHKQCEDVRAYSFRNKPIIVSAETAGNGLYNFIVPLRASYRPRQELNPIVLLLDNPPEPQFLETICWFPMIYYMVGSMDSLDDLLRCGVSY 817 rSlack VKAPFCCLRLDKGCKHNSYEDAKAYGFKNKLIIVSAETAGNGLYNFIVPLRAYYRSRRELNPIVLLLDNKPDHHFLEAICCFPMVYYMEGSVDNLDSLLOCGIIY 817 rSlick EKVPFCCLRLDKSCQHNYYEDAKAYGFKNKLI IVAAETAGNGLYNF IVPLRAYYRPKKELNPIVLLLDNPPDMHFLDAICWFPMVYYMVGSIDNLDDLLRCGVTF $\mathrm{Na}^{+}$

eSlack1 ADNLVVVDKESTMSAEEDYMADAKTIVNVQTMFRLFPSLSIITELTHPSNMRFMQFRAKDSYSLALSRLEKKERDKGSNLAFMFRLPFAAGRVFSISMLDTLLYQ 913 eSlack2 ADNLVVVDKESTMSAEEDYMADAKT IVNVQTMFRLFPSLSIITELTHPSNMRFMOFRAKDCYSLALSKLEKIERDKGSNLAFMFRLPFAAGRVFSISMLDTLLYO 930 eSlick AANMVVVDKESTMSAEEDYMADAKT IVNVQTLFRLFSGLSITTELTHPANMRFMOFRAKDSYSLALSKLEKOERENGSNLAFMFRLPFAAGRVFSISMLDTLLYO O22 rSlack $\begin{aligned} \text { rSlack } & \text { ADNLVVVDKESTMSAEEDYMADAKT IVNVQTMFRLFPSLSITTELTHPSNMRFMQFRAKDCYSLALSKLEKKERERGSNLAFMFRLPFAAGRVFSISMLDTLLYQ } \\ \text { rSlick } & \text { AANMVV } \\ & \end{aligned}$

eSlack1 CFVKDYMILITRLLLGLDTTPGSGYLCAMRVCECDLWIRTYGRLFOKLCSTSSEIPIGLYRTESHMFLSS - . - . - . - . - . - ESQCSVSTEGLADTKEKGE - 1002 eSlack2 SFVKDYMIPIARLLLGLDTTPGSGYLCVIKVTEDDLWIRTYGRLFQKLCSSSAEIPIGLYRTESHVFSSS - . - . - . - . - . EVEEKPPGYLMFLVRPLTQ- 1019

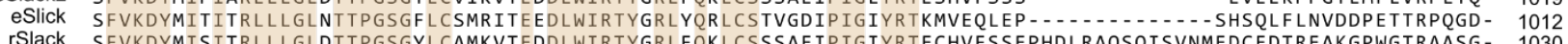
$\begin{aligned} \text { rSlack } & \text { SFVKDYMISITRLLLGLDTTPGSGYLAMKVTEDDLWIRTYGRLFQKLCSSSAEIPIGIYRTECHVFSSEPHDLRAQSQISVNMEDCEDTREAKGPWGTRAASG- 1030 } \\ \text { rSlick } & \text { SFVKDYVITITRLLLGLDTIPGSGFLCSMKITEDDLWIRTYARLYQKLCSSTGDVPIGIYRTESQKLTTS-_. }\end{aligned}$

ESlack1 -EPKILTRSSSGSDQSEHPLLRRKSMHWTRRLSRRTMKRSDSSFFS - - - AQPKHSVFRRSEREELTELVRNRMQHLGLHTG-FKDITNLTASDVMNRLNLGYLQ 1101

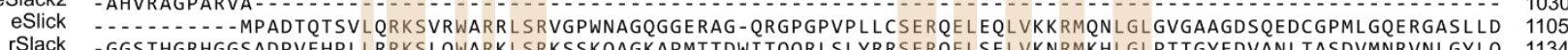

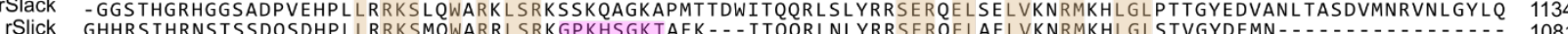
ATP

ESlack1 GELNDHQN-SLSYVLINPAPDTHLQLNDVVFLIRPDPLAHVPDEPPIRTRSKEPIPDTPERDQL - - - -

eSlack2 -

eSlick SEEINGNNNSHSYVLINPPPDTRLEVHDIVYIIRESPLLFVSSDEDSRKSSTENSSCGWOEELY . . .

rSlack DEMNDHHONTLSYVLINPPPDTRLEPNDIVYLIRSDPLAHVTSSSOSRKSSCSNKLSSCNPETRDETQL

Fig. 3. Amino acid sequences of $\boldsymbol{E}$. virescens $\mathbf{K}_{\mathrm{Na}}$ channels. $A$ : Multiple sequence alignment was run by the Clustal W program using the Geneious software. Identical amino acids among all five sequences are shaded in brown except the C-terminal tail, where residues shared by eSlack1, eSlick, rSlack and eSlick are also highlighted. Gaps are represented by dashed lines. In the cytoplasmic N-terminus, identical residues are colored in blue. Red residues represent the membrane spanning domains (S1-6) and the pore region (P) of the five $\mathrm{K}_{\mathrm{Na}}$ channels. Within the pore forming loop, the conserved residues determining the channel's specific selectivity to $\mathrm{K}^{+}$ions are highlighted with green box. Residues shaded in gray represent the $\mathrm{Na}^{+}$coordination motifs in rat Slack and Slick. Residues composing the ATP binding motif of rat Slick are shaded in magenta. 
131 between S5 and S6, and an extensive C-terminal region (Figs. 3,4). At the homologous position

132 of the $\mathrm{Na}^{+}$coordination motif of rat Slick subunit (ㅁNPPDM프) [35], E. virescens Slick has the

133 sequence DNPPEPQ, which shares four of seven residues in common with rat Slick, and does

134 not end with histidine $(\mathrm{H})$. Histidine $(\mathrm{H})$ may not be necessary for binding $\mathrm{Na}^{+}$, as it was shown

135 in rat Slick that mutation of the aspartic acid (D) residue dramatically decreased the channel's

136 sensitivity to $\mathrm{Na}^{+}$, whereas histidine $(\mathrm{H})$ substitution barely changed the channel's function [35].

137 Rat and human Slick channels are ATP-regulated channels, and can be directly inhibited by

138 intracellular ATP. The molecular determinants of ATP sensitivity is the presence of the "Walker

139 A motif" (GxxxxGKT) on the distal C-terminus of Slick subunits $[25,36]$. The residues at the

140 homologous position of the "Walker A motif" in rat Slick are not well conserved between rat and

141 E. virescens Slick. Furthermore, there is no motif having the signature residues of the "Walker

142 A motif' in the C-terminus of E. virescens Slick subunits. Whether E. virescens Slick channels

143 are regulated by intracellular ATP levels needs to be determined by future electrophysiology

144 studies. 
bioRxiv preprint doi: https://doi.org/10.1101/2021.03.08.434486; this version posted March 9, 2021. The copyright holder for this preprint (which was not certified by peer review) is the author/funder, who has granted bioRxiv a license to display the preprint in perpetuity. It is made available under aCC-BY-NC-ND 4.0 International license.

Coregulation of ionic conductances - 12
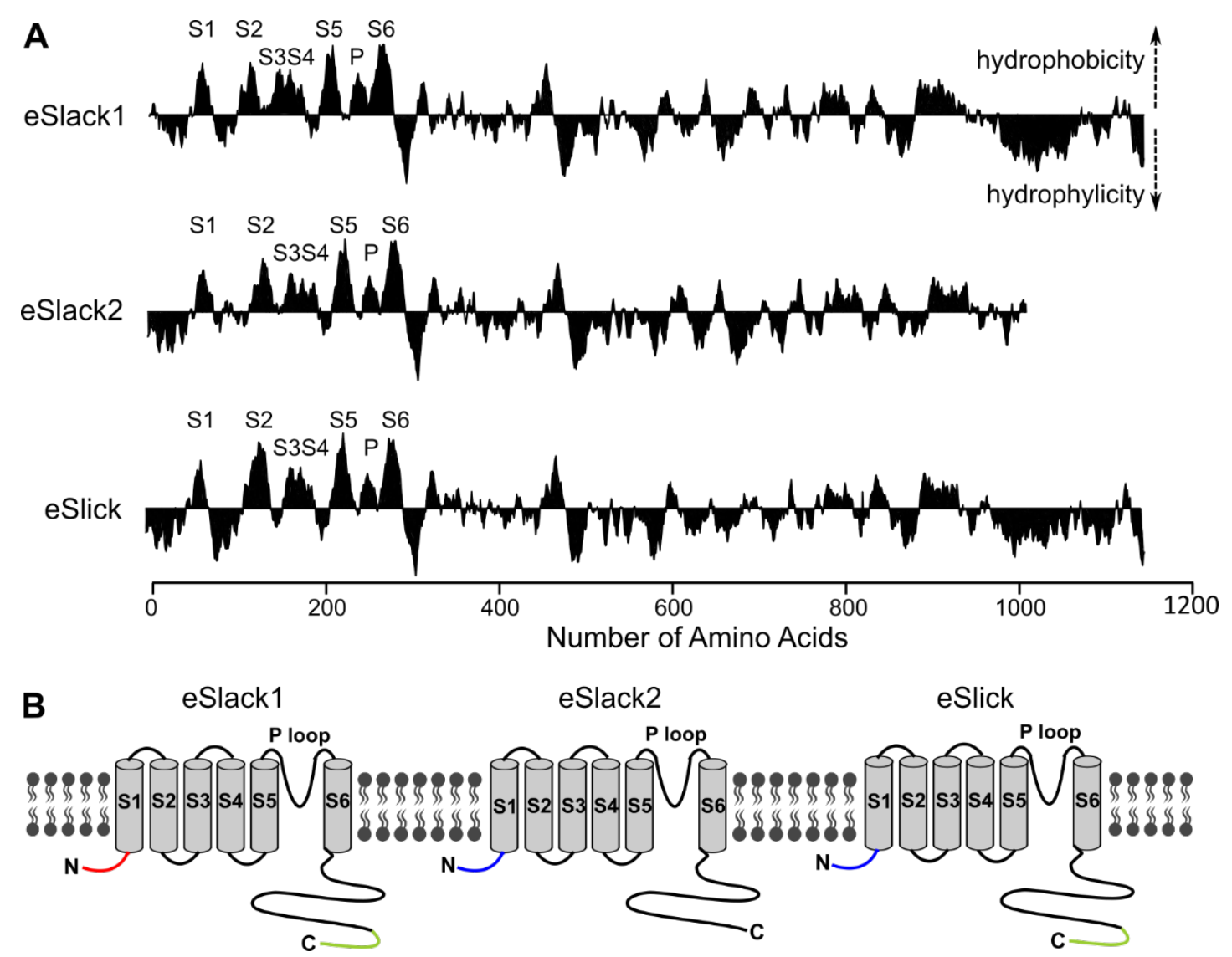

Fig 4. Predicted secondary structure of $\boldsymbol{E}$. virescens $\mathbf{K}_{\mathrm{Na}}$ channels. $B$ : Kyte-Doolittle hydrophilicity plot of E. virescens $\mathrm{K}_{\mathrm{Na}}$ channels (window size of 19 amino acids). C: Schematic representation of E. virescens $\mathrm{K}_{\mathrm{Na}}$ channel subunits. eSlack2 and eSlick have identical N-terminus (blue), which is different from that of eSlack1(red). The C-terminal tail of eSlack2 is shorter than that of eSlack1 and eSlick (green). 
OAAJ11822) [38] and the three E. virescens $\mathrm{K}_{\mathrm{Na}}$ subunits showed that the $\mathrm{K}_{\mathrm{Na}}$ channel antibody the tag to construct the recombinant $E$. virescens $\mathrm{K}_{\mathrm{Na}}$ channel subunits. separated by a flexible polylinker containing glycine $(\mathrm{G})$ polypeptide with serine $(\mathrm{S})$ inserts to allow the proper folding and function of both molecules [40-42]. The fusion of a fluorescent

170 protein to a native protein may affect the protein's normal localization. To ensure N-terminal 171 mCherry fusion does not affect the trafficking of eSlack/Slick subunits to the plasma membrane,

172 we examined the membrane expression of these recombinant $\mathrm{K}_{\mathrm{Na}}$ channel subunits in Xenopus

173 laevis (X. laevis) oocytes and showed that all of them could be successfully expressed on cell

174 membranes (Fig. 5A). Next we injected mCherry-eSlack1, mCherry-eSlack2, or mCherry-eSlick

175 expression vectors into the EO and performed live-cell imaging of electrocytes 10 days later. We 176 found that mCherry-eSlack1 localized on the anterior region of the electrocyte, mimicking the 177 distribution of endogenous eSlack1 detected by immunohistochemistry [38] (Fig. 5C), providing 
bioRxiv preprint doi: https://doi.org/10.1101/2021.03.08.434486; this version posted March 9, 2021. The copyright holder for this preprint (which was not certified by peer review) is the author/funder, who has granted bioRxiv a license to display the preprint in perpetuity. It is made available under aCC-BY-NC-ND 4.0 International license.

Coregulation of ionic conductances - 14

178 evidence that N-terminal mCherry fusion does not affect the normal localization of eSlack/Slick

179 subunits. Similar to mCherry-eSlack1, the expression of mCherry-eSlack2 and mCherry-eSlick

180 was only detected on the anterior region (Fig. 5D,E). These results indicate that the three $E$.

181 virescens $\mathrm{K}_{\mathrm{Na}}$ channel subunits all are expressed only on the anterior region of the electrocyte. 
bioRxiv preprint doi: https://doi.org/10.1101/2021.03.08.434486; this version posted March 9, 2021. The copyright holder for this preprint (which was not certified by peer review) is the author/funder, who has granted bioRxiv a license to display the preprint in perpetuity. It is made available under aCC-BY-NC-ND 4.0 International license.

Coregulation of ionic conductances - 15


Anterior
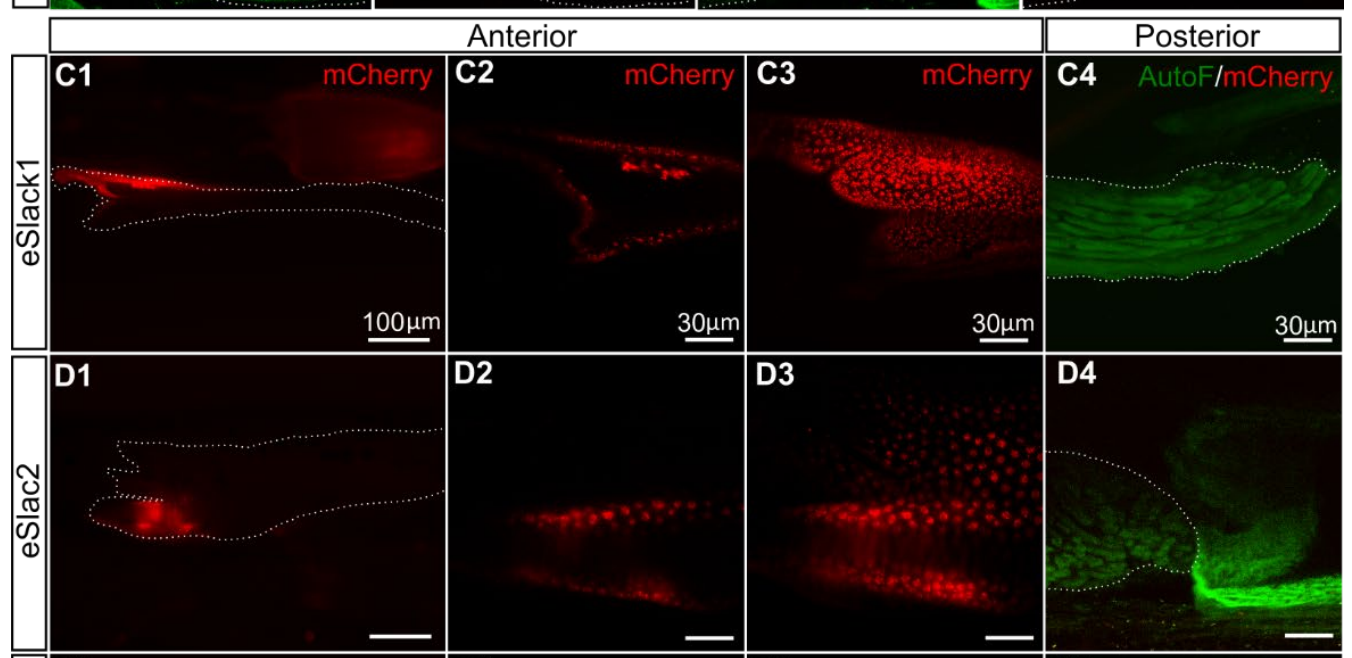

D4
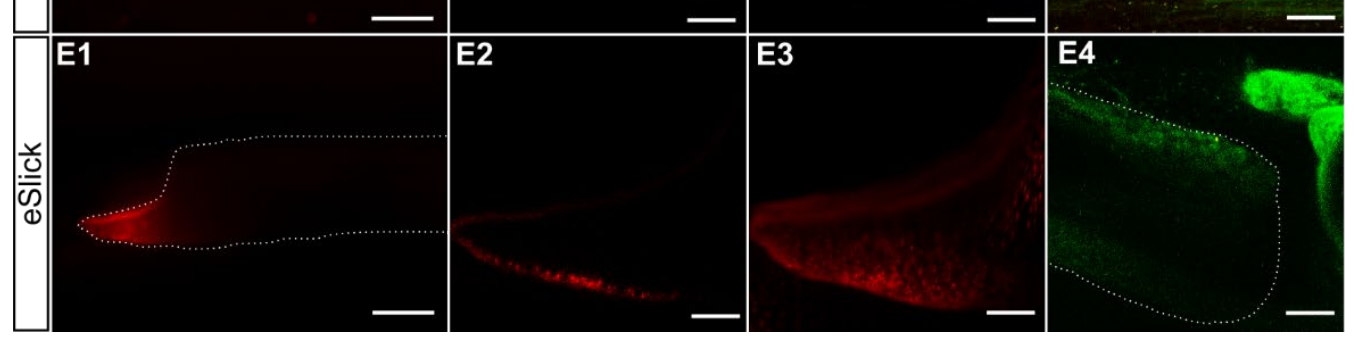

Fig. 5. Expression of mCherry-tagged $\mathrm{K}_{\mathrm{Na}}$ channels on the plasma membrane of $X$. laevis oocytes and localization of $\mathbf{K}_{\mathrm{Na}}$ channels in electrocytes. A. Maximum-intensity-projection (MIP) images of X. laevis oocytes expressing mCherry tagged $E$. virescens $\mathrm{K}_{\mathrm{Na}}$ channels rendered with images taken at different focal planes. B: MIP images of a control electrocyte (no expression of mCherry-tagged $\mathrm{K}_{\mathrm{Na}}$ channels). Broadband tissue autofluorescence (AutoF, green) was excited by a 488-nm laser. $C-E$ : Representative images of electrocytes expressing mCherry-eSlack/Slick plasmids on the anterior region. Images in C1, D1 and E1, acquired using an epifluorescent microscope, show a larger field of view. Other images in C-E were acquired by laser-scanning confocal microscope. Images displayed in C2, D2 and E2 are single optical sections showing the anterior face from cells expressing recombinant $\mathrm{K}_{\mathrm{Na}}$ channels (red). C3, D3 and E3 are MIP images rendered from the serial optical sections shown in C2, D2 and E2. Merged images of autofluorescence (green) and mCherry (red) in C4, D4 and E4 revealed that recombinant $\mathrm{K}_{\mathrm{Na}}$ channels are not expressed on the posterior membrane of electrocytes. White dotted lines indicate the boundary of electrocytes. 


\section{Coregulation of ionic conductances - 16}

183

184

185

186

187

188

189

190

191

192

193

194

195

196

197

198

199

200

201

202

203

204

\section{Characteristics of eSlack/eSlick currents}

The only outward $\mathrm{K}^{+}$current in E. virescens electrocytes is a noninactivating $\mathrm{Na}^{+}$activated $\mathrm{K}^{+}$current $\left(\mathrm{I}_{\mathrm{KNa}}\right)$ [14]. To determine how the three $\mathrm{K}_{\mathrm{Na}}$ channels identified here contribute to outward $\mathrm{K}^{+}$currents, we expressed these $\mathrm{K}_{\mathrm{Na}}$ channels in $X$. laevis oocytes to characterize and compare their electrophysiological properties. Both eSlack1 and eSlick constructs produced robust outward $\mathrm{K}^{+}$currents. Whole-cell currents from cells injected with eSlack1 cRNA showed much slower activation than those injected with eSlick cRNA (Fig. 6A). At test potentials positive to $-40 \mathrm{mV}$, eSlack1 activates with relatively slow time constants (Fig. $6 \mathrm{~A}$ and $\mathrm{B})$. The $\tau-\mathrm{V}$ relationship eSlack1 activation shows that eSlack1 currents activate slower as membrane potential becomes more depolarized until $+10 \mathrm{mV}$, after which activation becomes more rapid with more depolarized membrane potentials (Fig. 6C). In contrast, eSlick shows rapid activation. Whole-cell currents in eSlick cRNA injected oocytes activated nearly instantaneously with step changes in voltage to test potentials positive to $-70 \mathrm{mV}$ (Fig. 6A and B). eSlick activation $\tau$ decreases with more depolarized membrane potentials reaching a minimum at +20 $\mathrm{mV}$ (Fig. 6D). The plateau is likely due to the inward-rectification. We used water-injected oocytes as controls. As reported previously, control cells could express an endogenous $\mathrm{Ca}^{+}-$ activated $\mathrm{Cl}^{-}$current and $\mathrm{Na}^{+}$-activated $\mathrm{K}^{+}$current, the magnitude of which is much smaller compared to cells expressing exogenous currents (Fig. 6A) [43, 44]. Unlike for eSlack1 and eSlick, oocytes injected with eSlack2 cRNA expressed currents which are not distinguishable from those of control cells (Fig. 6A). The C-terminal tail of eSlack2 is approximately 100-amino acids shorter than eSlack1 and eSlick. Since mCherry-eSlack2 can be expressed on the plasma membrane of both $X$. laevis oocytes and electrocytes, the absence of currents is not likely due to 
bioRxiv preprint doi: https://doi.org/10.1101/2021.03.08.434486; this version posted March 9, 2021. The copyright holder for this preprint (which was not certified by peer review) is the author/funder, who has granted bioRxiv a license to display the preprint in perpetuity. It is made available under aCC-BY-NC-ND 4.0 International license.

Coregulation of ionic conductances - 17

205

206

207

208

A

control
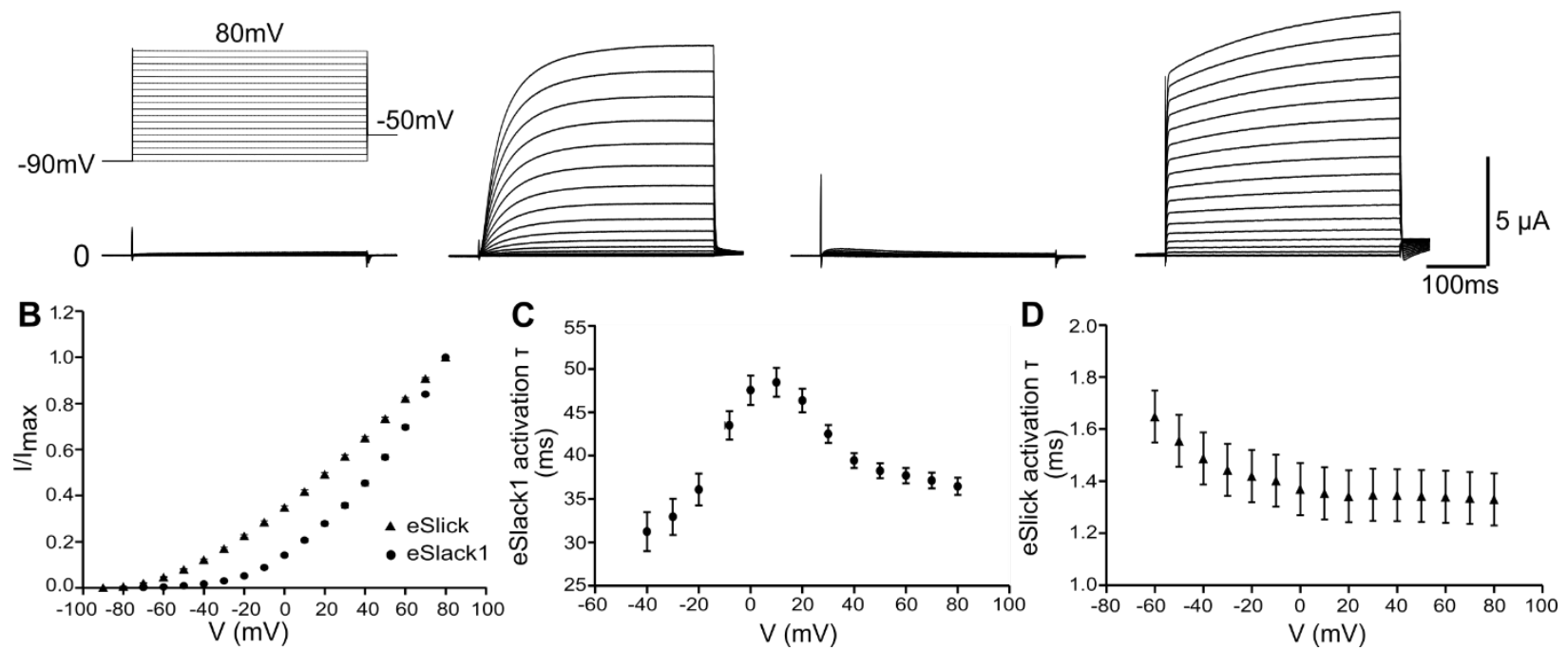

Fig. 6. Whole cell recordings of $X$. laevis oocytes expressing $E$. virescens $\mathbf{K}_{\mathrm{Na}}$ channels. $A$ : Whole cell currents recorded when oocytes were depolarized by $400 \mathrm{~ms}$ voltage steps ranging from $-90 \mathrm{mV}$ to $+80 \mathrm{mV}$ in $10 \mathrm{mV}$ increments every $5 \mathrm{~s}$ from a holding potential of $-90 \mathrm{mV}$. B: Current-voltage relationship of oocytes expressing eSlack1 (circle; $\mathrm{n}=13$ ) and eSlick (triangle; $\mathrm{n}=10$ ) channels. Current amplitude was measured as the mean amplitude during the last $30 \mathrm{~ms}$ of each pulse, and divided by the maximal current amplitude. $C$ - $D$ : Activation time constant $(\tau)$ of eSlack1 $(C ; n=13)$ and eSlick $(D ; n=10)$ currents were plotted as a function of membrane potential. with $2 \mathrm{M} \mathrm{NaCl}$ would allow $\mathrm{Na}^{+}$to diffuse into the cell and thereby increase $\left[\mathrm{Na}^{+}\right]_{\mathrm{i}}[35,45]$. We applied the same method to increase $\left[\mathrm{Na}^{+}\right]$ind measured the amplitude of currents when the cell 
217 suggesting that eSlack1 and eSlick have basal levels of activity even at intraoocyte $\mathrm{Na}^{+}$

218 concentrations of $\sim 10 \mathrm{mM}[46]$ (Fig. 7A).

219 During a 9-min recording, the peak amplitude of both eSlack1 and eSlick at membrane

220 potential of $+20 \mathrm{mV}$ was elevated with $\mathrm{NaCl}$ diffusing into the cell (Fig. 7A and $\mathrm{C}$ ). To

221 distinguish the role of $\mathrm{Na}^{+}$and $\mathrm{Cl}^{-}$in increasing current amplitude, we also used microelectrodes

222 filled with $2 \mathrm{M} \mathrm{KCl}$ and measured the peak amplitude of both eSlack1 and eSlick within 9 min.

223 The currents of eSlack1 stayed constant with increased intracellular levels of KCl. In contrast,

224 eSlick showed increased current magnitudes with $\mathrm{KCl}$-filled electrodes (Fig. 7B and C). The

225 peak current of control cells at $+20 \mathrm{mV}$ remained constant during 9-min loading of either $2 \mathrm{M}$

$226 \mathrm{NaCl}$ or $\mathrm{KCl}$ (Fig. 7) . These results suggest that eSlack1 has an absolute requirement of $\mathrm{Na}^{+}$to

227 increase the channel's open probability, whereas, eSlick channels are more sensitive to

228 intracellular $\mathrm{Cl}^{-}$levels. 
bioRxiv preprint doi: https://doi.org/10.1101/2021.03.08.434486; this version posted March 9, 2021. The copyright holder for this preprint (which was not certified by peer review) is the author/funder, who has granted bioRxiv a license to display the preprint in perpetuity. It is made available under aCC-BY-NC-ND 4.0 International license.

Coregulation of ionic conductances - 19

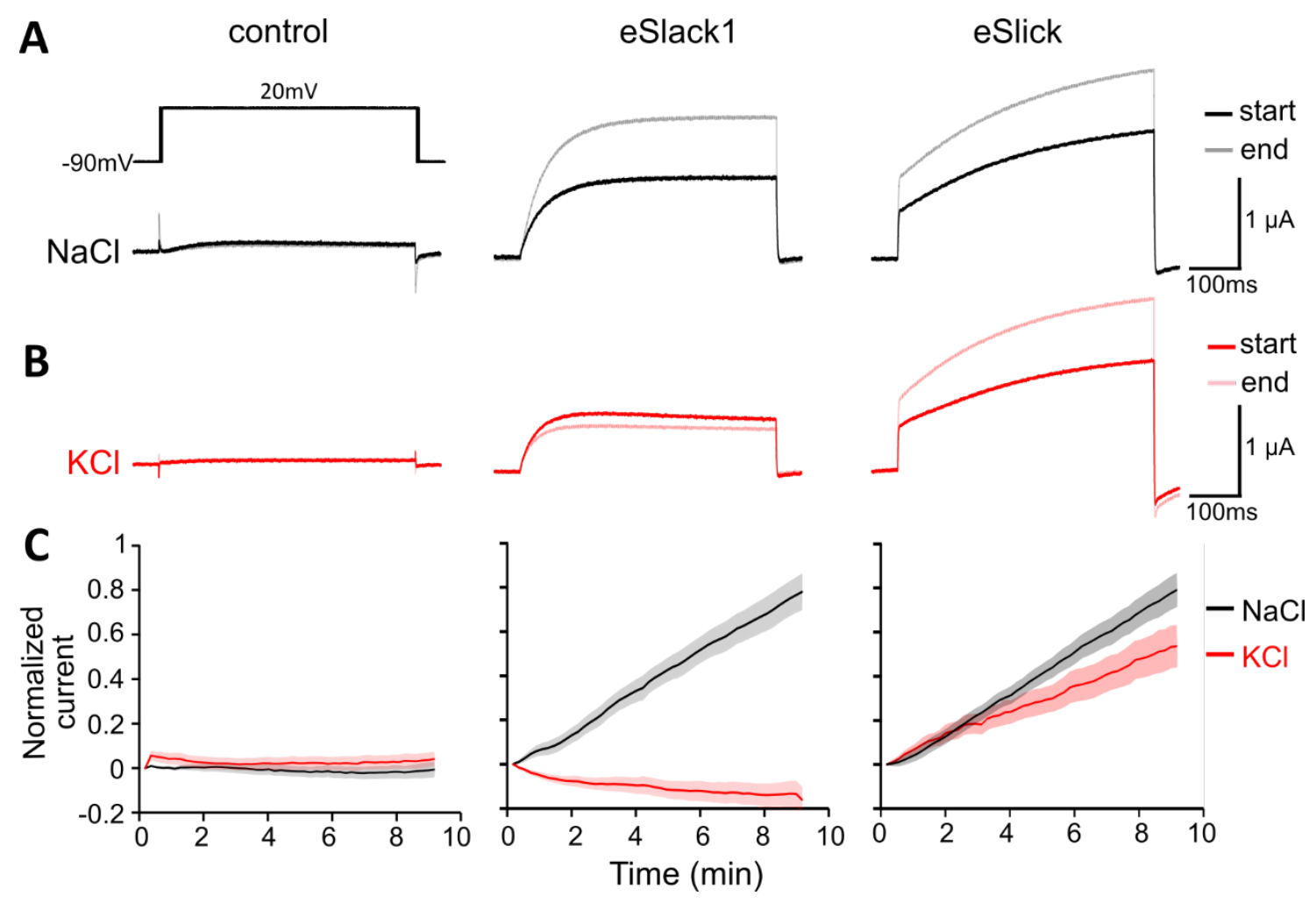

Fig. 7. Whole cell currents ofeSlack1 and eSlick with microelectrodes filled with $2 \mathrm{M} \mathrm{NaCl}$ or $\mathrm{KCl}$. Oocytes were depolarized by a $500 \mathrm{~ms}$ pulse to $+20 \mathrm{mV}$ from a holding potential of $-90 \mathrm{mV}$ every $10 \mathrm{~s}$. $A$ : With both microelectrodes filled with $2 \mathrm{M} \mathrm{NaCl}$, whole cell currents recorded from control oocytes (left), oocytes expressing eSlack1 channels (middle), and oocytes expressing eSlick channels (right) immediately after impaling the cell (start; black) and after 9 min of loading (end; gray). $B$ : Whole cell currents recorded from the three types of oocytes mentioned above immediately after impaling the cell (start; red) and 9 min after (end; pink), with both microelectrodes filled with $2 \mathrm{M} \mathrm{KCl}$ solution. $C$ : Current amplitudes were normalized to the current recorded at "start", and taken the log (base 2). Normalized current amplitudes from control cells (left), cells expressing eSlack1 (middle) and cells expressing eSlick (right)were plotted against time with $2 \mathrm{M} \mathrm{NaCl}$ (black) or $\mathrm{KCl}$ (red) loaded to the cell. Measurements from 8 cells in each group were analyzed. Standard error was shown as gray or pink shades.

\section{Transcription levels of eSlick increase with EOD frequency}

Hz) [8] (Fig. 1E). Previous studies in a closely related species Sternopygus macrurus have shown 
EOD frequencies $(192$ Hz, 206 Hz, 229 Hz, 250 Hz, 300 Hz, 333 Hz, 350 Hz, 380 Hz, 395 Hz,

$426 \mathrm{~Hz}$ ) spanning most of the species' natural range, and measured the transcription levels of the

(Mean) \pm 0.95 (SEM); Student's t-test, $p=0.647$ ) (Fig. 8C).

\section{Transcription levels of $\mathrm{Na}$ 1.4a, Kir6.2 and $\mathrm{Na}^{+} / \mathrm{K}^{+}$ATPase increase with EOD frequency}

255 The $\mathrm{Na}_{\mathrm{v}}$ channels in the $\mathrm{EO}$ of $E$. virescens are encoded by a pair of duplicated genes, $\mathrm{Na}_{\mathrm{v}} 1.4 \mathrm{a}$ 
259 in both muscle and EO, whereas, $\mathrm{Na}_{\mathrm{v}} 1.4 \mathrm{a}$ and the $\alpha$-subunit of $\mathrm{Na}^{+} / \mathrm{K}^{+}$ATPases are dominantly expressed in the EO (data not shown). We reasoned that EOD frequency might also correlated with expression levels of these ion channels and $\mathrm{Na}^{+} / \mathrm{K}^{+}$ATPases.

With real-time PCR, we measured the mRNA levels of these genes from the EOs of the same 10 fish used in the previous experiment. Results showed that the transcription levels of

$264 \mathrm{Na}_{\mathrm{v}} 1.4 \mathrm{a}$, Kir6.2 and $\mathrm{Na}^{+} / \mathrm{K}^{+}$ATPase increased exponentially with EOD frequency (Fig. 8B1, B3 265 and B4, and Fig. 9D, F and G). No correlation between the transcription level of $\mathrm{Na}_{\mathrm{v}} 1.4 \mathrm{~b}$ and 266 EOD frequency was detected (Fig. 8B2 and Fig. 9E). When comparing the mean transcription

267 level of genes between the two groups of fish with high and low EOD frequencies, significant 268 difference was detected in Nav1.4a (high frequency: $n=5,3.89$ (Mean) \pm 0.72 (SEM); low

269 frequency: $\mathrm{n}=5,1.38$ (Mean) \pm 0.17 (SEM); Student's t-test, $p=0.009$ ), Kir6.2 (high frequency:

$270 \mathrm{n}=5,3.18($ Mean $) \pm 0.55($ SEM); low frequency: $\mathrm{n}=5,1.16$ (Mean) $\pm 0.13(\mathrm{SEM})$; Student's t-

271 test, $p=0.007$ ) and $\mathrm{Na}^{+} / \mathrm{K}^{+}$-ATPase (high frequency: $\mathrm{n}=3,6.84$ (Mean) $\pm 1.28(\mathrm{SEM})$; low

272 frequency: $\mathrm{n}=5,1.57($ Mean) $\pm 0.61(\mathrm{SEM})$; Student's t-test, $p=0.005)$, but not Na $1.4 \mathrm{~b}$ (high

273 frequency: $\mathrm{n}=5,1.28$ (Mean) $\pm 0.19(\mathrm{SEM})$; low frequency: $\mathrm{n}=5,1.32($ Mean $) \pm 0.19(\mathrm{SEM})$;

274 Student's t-test, $p=0.887$ ) (Fig. 8C). 
bioRxiv preprint doi: https://doi.org/10.1101/2021.03.08.434486; this version posted March 9, 2021. The copyright holder for this preprint (which was not certified by peer review) is the author/funder, who has granted bioRxiv a license to display the preprint in perpetuity. It is made available under aCC-BY-NC-ND 4.0 International license.

Coregulation of ionic conductances - 22

A $\begin{array}{lllll}\text { eSlack1 } & \text { B } & \text { eSlack2 } & \text { C } & \text { eSlick }\end{array}$
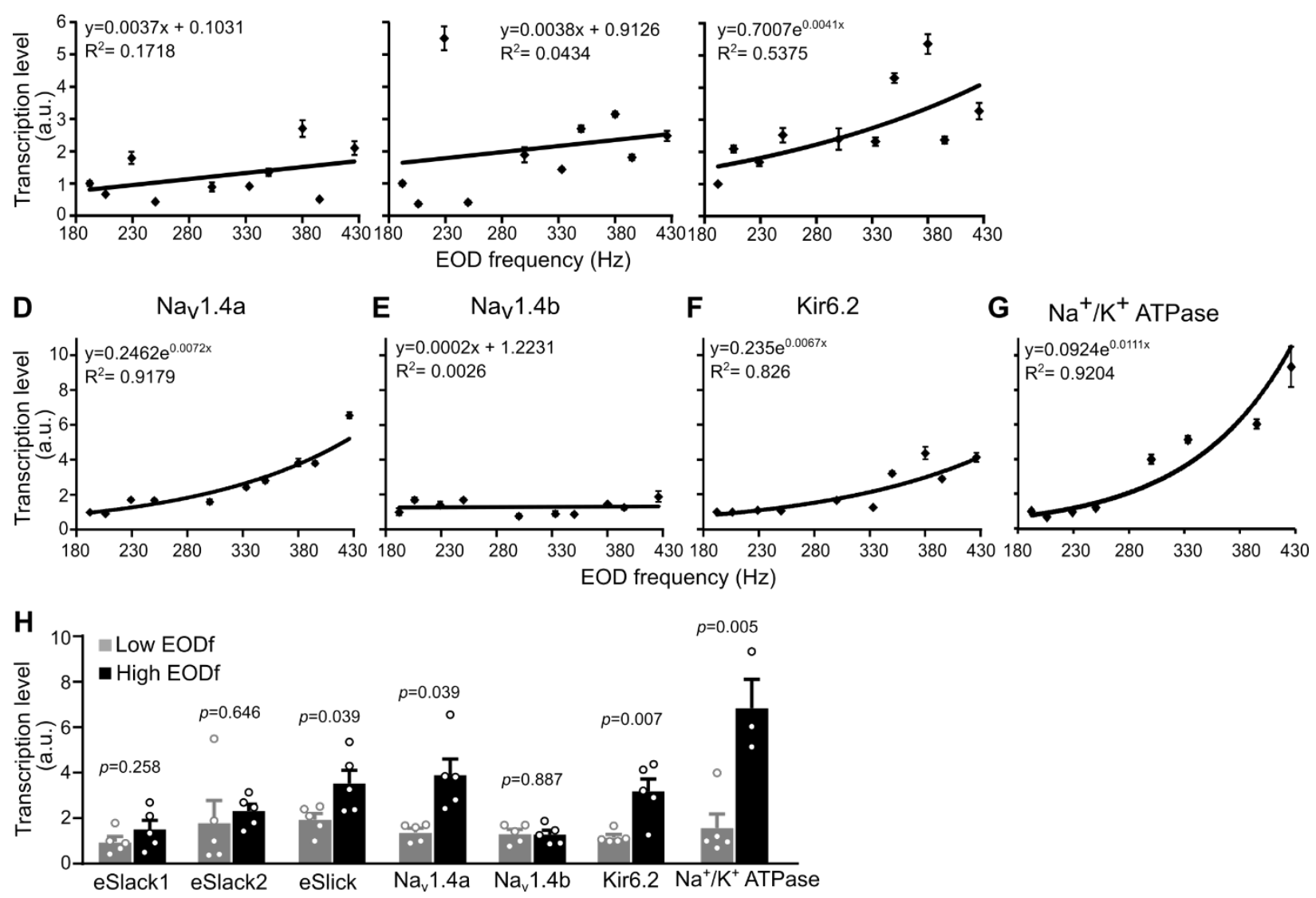

Fig. 8. Real-time PCR quantification of ion channel genes in EOs from $E$. virescens with different EOD

frequencies. $A-B$ : The normalized transcription levels of target genes were plotted against EOD frequency. $A$ : The transcription level of eSlack1 (A1) and eSlack2 (A2) in the EO do not correlate with EOD frequency. The transcription level of eSlick increases with EOD frequency (A3). B: The transcription levels of $\mathrm{Na}_{\mathrm{v}} 1.4 \mathrm{a}$ (B1), Kir6.2 (B3) and $\mathrm{Na}^{+} / \mathrm{K}^{+}$ ATPase (B4) in EO from fish with different EOD frequencies can be fitted into an exponential curve. There is no correlation between the normalized amounts of $\mathrm{Na}_{\mathrm{v}} 1.4 \mathrm{~b}$ (B2) transcripts in EO and EOD frequency. $C$ : Comparison of the mean transcription levels of genes between low $(<300 \mathrm{~Hz})$ and high $(>300 \mathrm{~Hz})$ frequency EOs. The average amounts of eSlick, $\mathrm{Na}_{\mathrm{v}} 1.4 \mathrm{a}$, Kir6.2 and $\mathrm{Na}^{+} / \mathrm{K}^{+}$ATPase in high frequency EOs are higher than that in low frequency EOs. There is no significant difference in the mean transcription levels of eSlack1, eSlack2 and $\mathrm{Na}_{\mathrm{v}} 1.4 \mathrm{~b}$ between high and low frequency EOs.. 
bioRxiv preprint doi: https://doi.org/10.1101/2021.03.08.434486; this version posted March 9, 2021. The copyright holder for this preprint (which was not certified by peer review) is the author/funder, who has granted bioRxiv a license to display the preprint in perpetuity. It is made available under aCC-BY-NC-ND 4.0 International license.

Coregulation of ionic conductances - 23

A

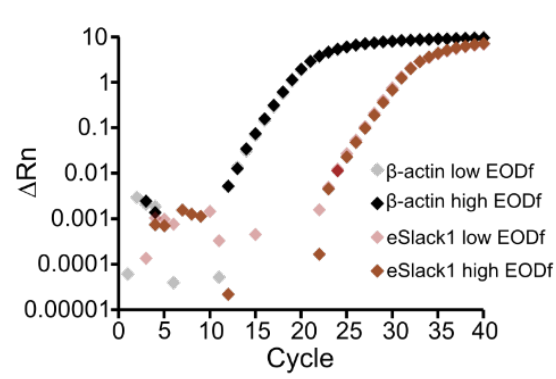

D $\quad \mathrm{Na}_{\mathrm{v}} 1.4 \mathrm{a}$

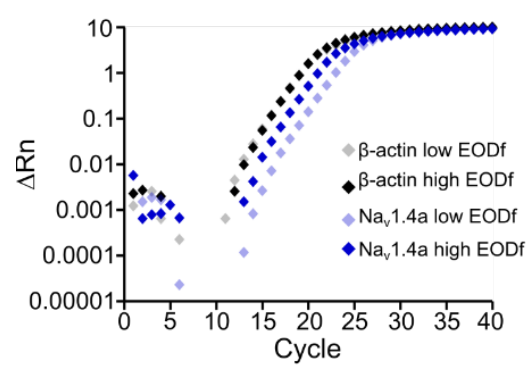

G $\quad \mathrm{Na}^{+} / \mathrm{K}^{+}$ATPase

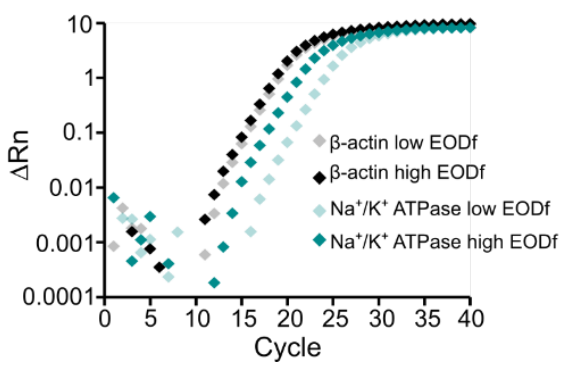

B

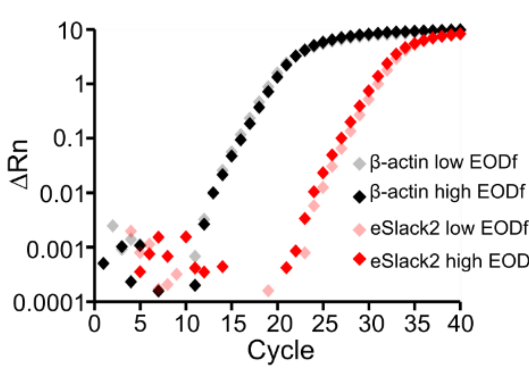

$\mathrm{Na}_{\mathrm{v}} 1.4 \mathrm{~b}$

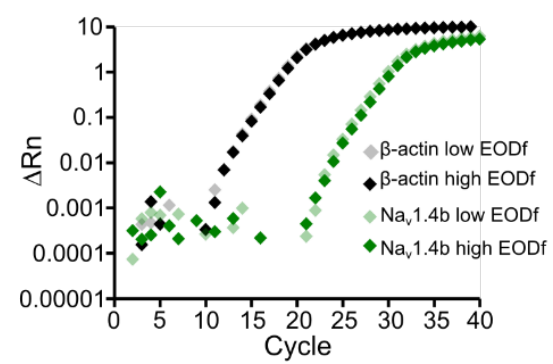

C

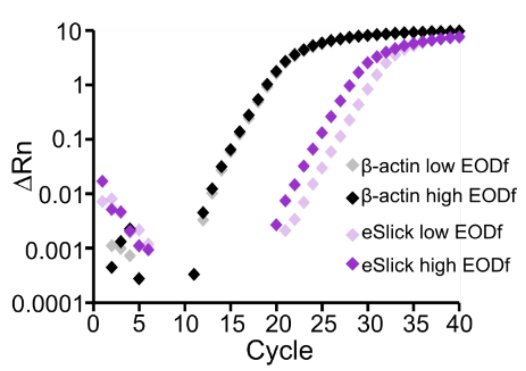

F $\quad$ Kir6.2

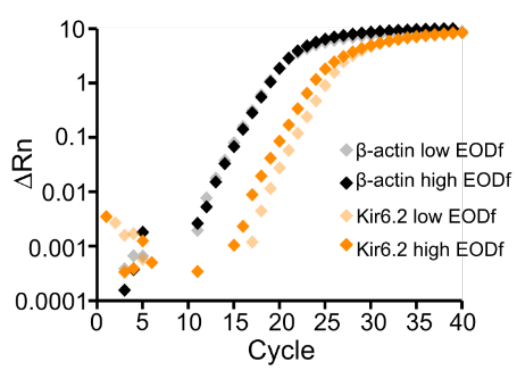

Fig. 9. Amplification of the target genes and endogenous control $\beta$-actin from EO cDNA of a fish with low EODf and a fish with high EODf. The amplifications of $\beta$-actin, eSlack1 (A), eSlack2 (B), and Nav1.4b (E) from EO cDNAs of fish with high and low EODf look identical. eSlick (C), $\mathrm{Na}_{\mathrm{v}} 1.4 \mathrm{a}$ (D), Kir6.2 (F), and $\mathrm{Na}^{+} / \mathrm{K}^{+}$ATPase $(\mathrm{G})$ started amplifying and reached the amplification plateau phase earlier when using EO cDNAs from a fish with high EODf than EO cDNAs from a fish with low EODf. 
Coregulation of ionic conductances - 24

277 Frequency-dependent scaling of multiple ionic conductances is necessary to maintain the integrity of simulated AP trains as EOD frequency increases. through intermediate AP frequencies then declined precipitously at higher AP frequencies, interval (Fig. 10i), with the model producing the most consistent AP amplitudes being the one 
300 that scaling these ionic conductances in a frequency-dependent manner consistent with our

301 mRNA expression data is necessary to maintain AP waveform integrity as AP frequency

302 increases.

Demand for $\mathrm{Na}^{+}$transport increases exponentially as EOD frequency increases.

Our simulations also suggest that an exponential scaling of $\mathrm{Na}^{+}, \mathrm{K}^{+}$-ATPase expression is necessary as EOD frequency increases. We calculated the required rate of $\mathrm{Na}^{+}$extrusion to

311 frequency, $\mathrm{Na}^{+}$clear rates increased exponentially. The greatest increases in $\mathrm{Na}^{+}$clear rate across

312 AP frequencies occurred in the last two model cells where where $\bar{g}_{N a}$ and $\bar{g}_{K N a}$, or $\bar{g}_{N a}, \bar{g}_{K N a}$,

313 and $\bar{g}_{R}$ scaled with AP frequency, thereby producing the greatest consistency in AP amplitudes

314 (Fig. 10j,k). 
bioRxiv preprint doi: https://doi.org/10.1101/2021.03.08.434486; this version posted March 9, 2021. The copyright holder for this preprint (which was not certified by peer review) is the author/funder, who has granted bioRxiv a license to display the preprint in perpetuity. It is made available under aCC-BY-NC-ND 4.0 International license.

Coregulation of ionic conductances - 26
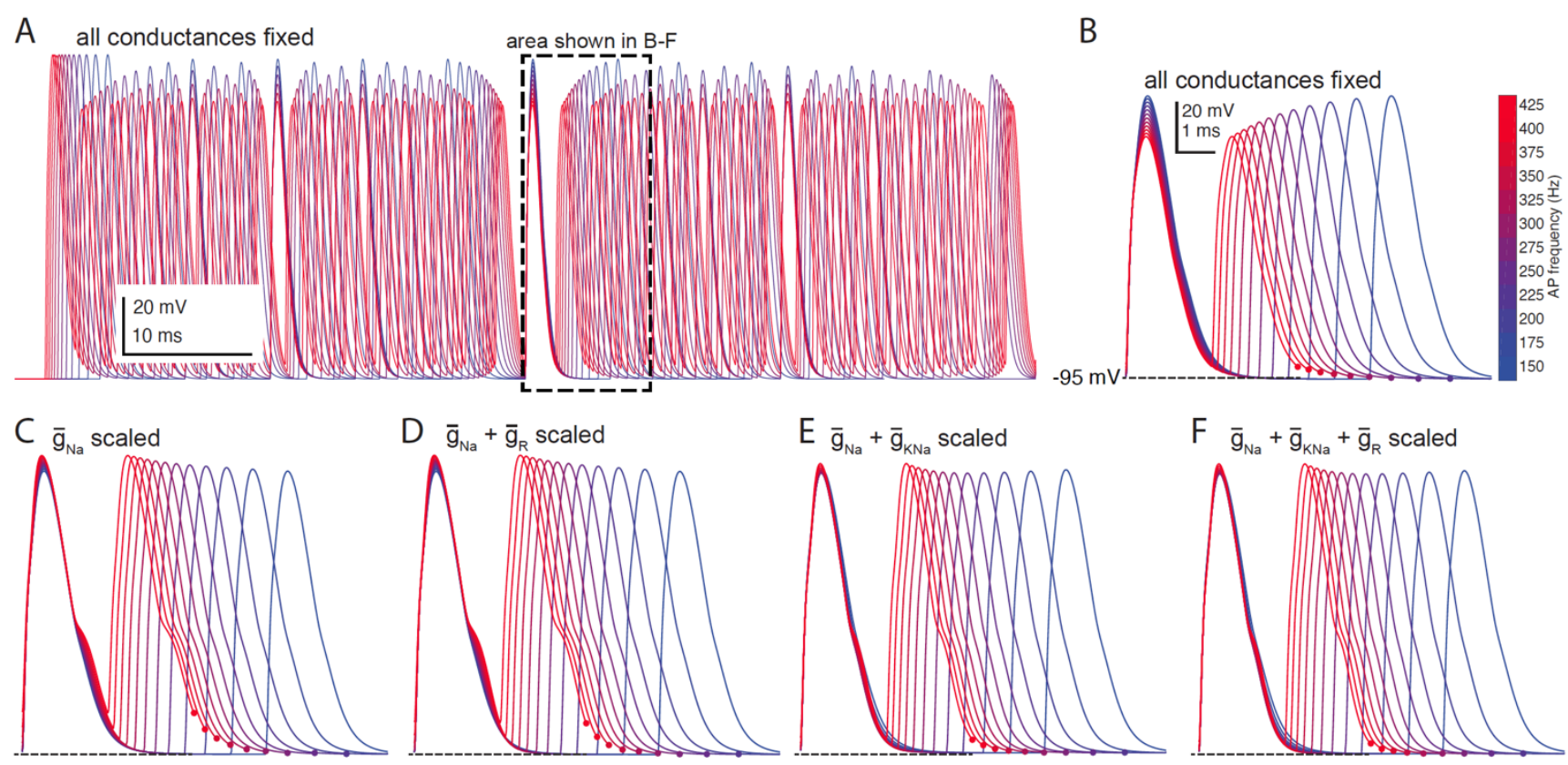

D $\overline{\mathrm{g}}_{\mathrm{Na}}+\overline{\mathrm{g}}_{\mathrm{R}}$ scaled

$\mathrm{E} \overline{\mathrm{g}}_{\mathrm{Na}}+\overline{\mathrm{g}}_{\mathrm{KNa}}$ scaled

$\mathrm{F} \overline{\mathrm{g}}_{\mathrm{Na}}+\overline{\mathrm{g}}_{\mathrm{KNa}}+\overline{\mathrm{g}}_{\mathrm{R}}$ scaled

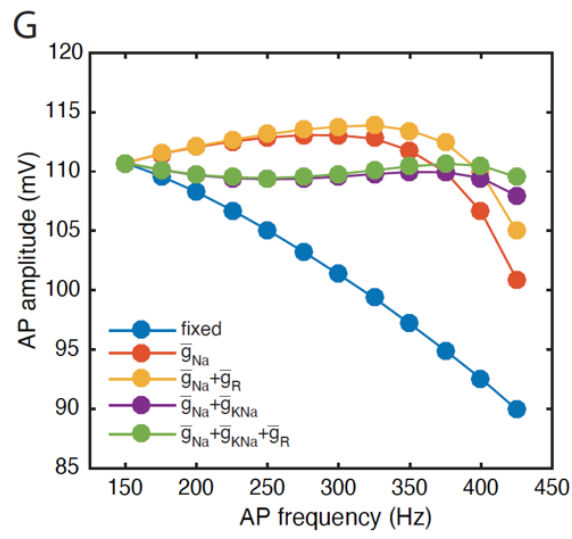

$\mathrm{H}$
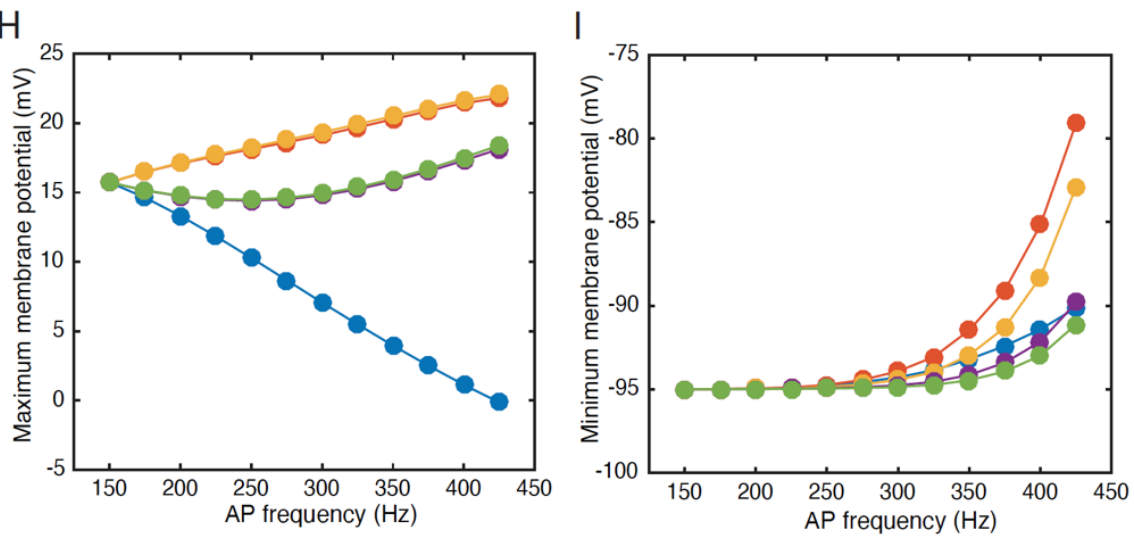

J
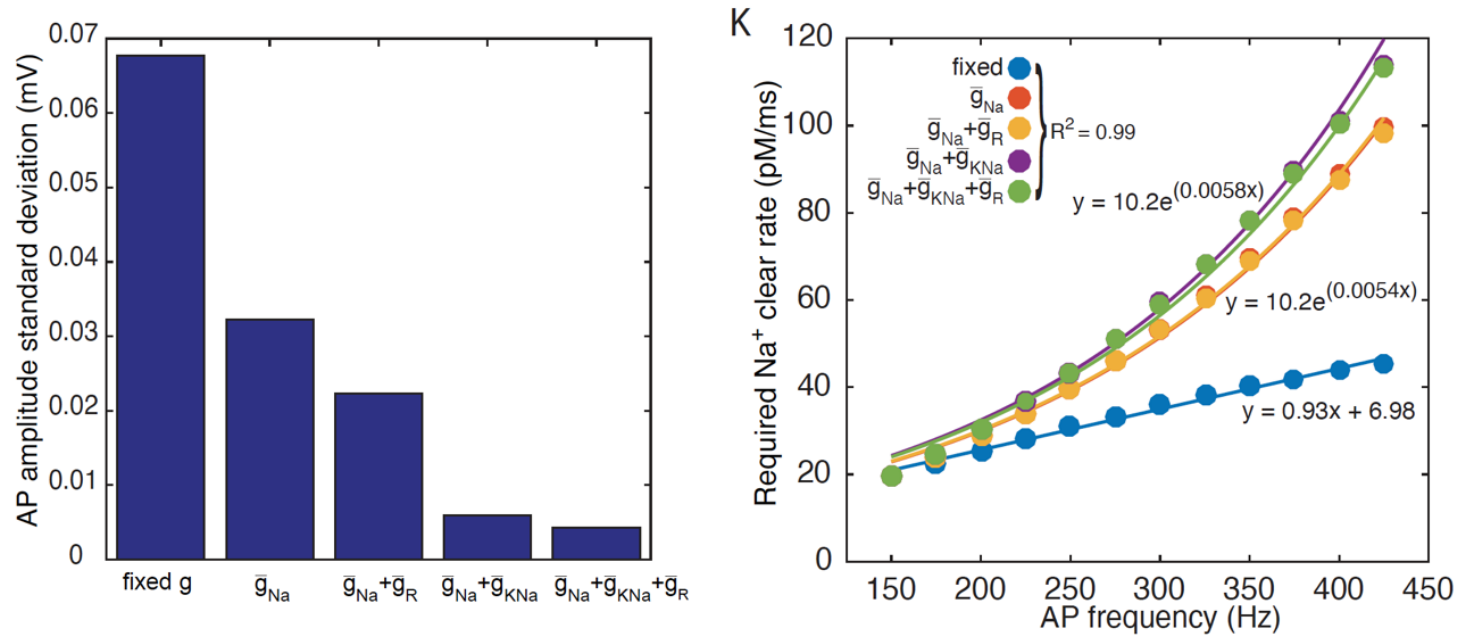

Fig. 10: (Caption next page.) 
bioRxiv preprint doi: https://doi.org/10.1101/2021.03.08.434486; this version posted March 9, 2021. The copyright holder for this preprint (which was not certified by peer review) is the author/funder, who has granted bioRxiv a license to display the preprint in perpetuity. It is made available under aCC-BY-NC-ND 4.0 International license.

Coregulation of ionic conductances - 27

Fig. 10. Computational simulations of electrocyte APs across AP frequencies in model electrocytes with and without scaled ionic conductances. (A) Superimposed trains of APs at frequencies from 150 $\mathrm{Hz}$ (blue) to $425 \mathrm{~Hz}$ (red) in $25 \mathrm{~Hz}$ steps, where all ionic conductances were held constant across AP frequencies The area within the dashed box is shown on expanded scale in $B$ through $F$. (B) Two sequential action potentials within each of the AP trains shown in $A$. Firing frequency is indicated according to the color map at right from $150 \mathrm{~Hz}$ (blue) to $425 \mathrm{~Hz}$ (red). Small color-coded circles indicate where the next AP in the train initiated (subsequent APs not shown for clarity). All ionic conductances were constant across AP frequencies. At higher AP frequencies, peak membrane potential during the AP decreased and AP repolarization was increasingly incomplete during the interspike interval. (C) Sequential APs represented as in $B$, where $\bar{g}_{N a}$ scaled exponentially with AP frequency according to the scaling equation $\bar{g}_{N a}=2300\left(0.264 e^{0.0057 x}\right)+700$. (D) Sequential APs where $\bar{g}_{N a}$ scaled with AP frequency as in $C$, and $\bar{g}_{R}$ scaled with AP frequency according to the equation $\bar{g}_{R}=100\left(0.235 e^{0.0067 x}\right)$. (E) Sequential APs where $\bar{g}_{N a}$ scaled with AP frequency as in $C$ and $\bar{g}_{K N a}$ scaled with AP frequency according to the equation $\bar{g}_{K N a}=2000\left(0.672 e^{0.0041 x}\right)$. (F) Sequential APs where $\bar{g}_{N a}$ and $\bar{g}_{K N a}$ scaled with AP frequency as in $E$ and $\bar{g}_{R}$ scaled with AP frequency as in $D$. (G) AP amplitude, measured peakto-trough for five model cells across AP frequencies from $150 \mathrm{~Hz}$ to $425 \mathrm{~Hz}$. Ionic conductances were fixed for all frequencies or various combinations of ionic conductances were varied in a frequencydependent manner as indicated in the legend. AP amplitude decreased significantly at higher frequencies where conductances were fixed. Consistency of AP amplitudes improved as conductances were scaled with frequency, with the greatest consistency across frequencies produced by the model cell where $\bar{g}_{N a}$, $\bar{g}_{K N a}$, and $\bar{g}_{R}$ were all scaled with AP frequency. (H) Peak membrane potential during the AP for the same five model cells in $G$. Ionic conductances were fixed for all frequencies or various combinations of ionic conductances were varied in a frequency-dependent manner as indicated in the legend. Peak membrane potential decreased significantly at higher frequencies where conductances were fixed. Consistency of peak AP potential improved as conductances were scaled with frequency, with the greatest consistency across frequencies produced by the model cell where $\bar{g}_{N a}, \bar{g}_{K N a}$, and $\bar{g}_{R}$ were all scaled with AP frequency. (I) Minimum membrane potential during the interspike interval for the same five model cells in $G$. Ionic conductances were fixed for all frequencies or various combinations of ionic conductances were varied in a frequency-dependent manner as indicated in the legend. Repolarization was most complete at higher frequencies for the model cell where $\bar{g}_{N a}, \bar{g}_{K N a}$, and $\bar{g}_{R}$ were all scaled with AP frequency. (J) Standard deviation of AP amplitude (as measured in $G$ ) across all AP frequencies for model cells where all ionic conductances were fixed, or scaled with frequency. The model cell with fixed conductances exhibited the largest variability in AP amplitude, while the model cell where $\bar{g}_{N a}, \bar{g}_{K N a}$, and $\bar{g}_{R}$ were all scaled with AP frequency showed the least variability in AP amplitude. (K) Required rate of $\mathrm{Na}^{+}$extrusion to restore $\mathrm{Na}^{+}$gradients $\left(\mathrm{Na}^{+}\right.$clear rate) for five model cells across AP frequencies from $150 \mathrm{~Hz}$ to $425 \mathrm{~Hz}$. Na ${ }^{+}$clear rate was computed as $\mathrm{pM}$ of $\mathrm{Na}^{+}$entering the cell during the AP divided by the interspike interval. Ionic conductances were fixed for all frequencies or various combinations of ionic conductances were varied in a frequency-dependent manner as indicated in the legend. Filled circles are individual data points. Solid lines indicate least-squares regression fits. Goodness of fit, as measured by $\mathrm{R}^{2}$ was equal across all model cells. The $\mathrm{Na}^{+}$clear rate increased in a linear fashion (equation shown in figure) for the model cell where all conductances were fixed. For cells where ionic conductances were varied with AP frequency, $\mathrm{Na}^{+}$clear rates increased exponentially according to the equations shown in the figure. The exponential equations were indistinguishable within rounding for the cells where $\bar{g}_{N a}$, or $\bar{g}_{N a}$ and $\bar{g}_{R}$, were varied as where the equations for cells where $\bar{g}_{N a}$ and $\bar{g}_{K N a}$, or where $\bar{g}_{N a}, \bar{g}_{K N a}$, and $\bar{g}_{R}$, were scaled. 


\section{Coregulation of ionic conductances - 28}

317

\section{DISCUSSION}

E. virescens electrocytes face a challenge that is unique among excitable cells: maintaining unremitting firing rates of 200 to $600 \mathrm{~Hz}$ throughout the lifespan while producing microAmp-scale ionic currents during each AP. How can these cells maintain these extremely high firing rates and satisfy equally extreme demands for the rapid restoration of ion gradients between APs? Our findings here provide several key insights about the ionic mechanisms that make these feats possible as well as their metabolic consequences. We found that electrocytes fulfill the fast-spiking requirement by exponentially increasing expression levels of multiple ion channels, including a novel rapidly-activating $\mathrm{K}_{\mathrm{Na}}$ channel isoform. Scaling expression levels of these channels to match firing rates is necessary for maintaining the integrity of the AP waveform as firing rates increase, but this comes at the cost of exponentially increasing demand for charge translocation by the $\mathrm{Na}^{+}, \mathrm{K}^{+}$-ATPase. Consistent with this conclusion we also found that $\mathrm{Na}^{+}, \mathrm{K}^{+}$-ATPase mRNA expression levels and electrocyte AP metabolic demand increase exponentially at higher firing rates.

We measured the mRNA levels of Nav1.4a, Nav1.4b, eSlack1, eSlack2, eSlick, Kir6.2 and $\mathrm{Na}^{+} / \mathrm{K}^{+}$ATPase in EO from E. virescens with different EODf and found that transcription levels of $\mathrm{Na}_{\mathrm{v}} 1.4 \mathrm{a}$, eSlick, Kir6.2 and $\mathrm{Na}^{+} / \mathrm{K}^{+}$ATPase are positively and exponentially correlated to EODf whereas levels of the other transcripts were not. Among the four genes that were correlated with EODf, $\mathrm{Na}_{\mathrm{v}} 1.4 \mathrm{a}$ and $\mathrm{Na}^{+} / \mathrm{K}^{+}$ATPase are predominantly expressed in $\mathrm{EO}$ and eSlick is expressed exclusively in EO, whereas Kir6.2 showed similar transcription levels in both muscle and EO, as was also the case for the genes that did not correlate with EODf $\left(\mathrm{Na}_{\mathrm{v}} 1.4 \mathrm{~b}\right.$, eSlack1, and eSlack2). Importantly, mRNA levels do not always predict its protein abundance, and we have not directly determined whether the abundance of corresponding proteins in 
340

341

342

343

344

345

346

347

348

349

350

351

352

353

354

355

356

357

358

359

360

361

electrocytes also correlates with EODf due to the lack of specific antibodies targeting most of the ion channels in electrocytes. However, our computational simulations strongly support the conclusion that expression of channel proteins in the cell membrane, in accordance with our observed mRNA expression levels, is required for the maintenance of AP waveform integrity across firing frequencies.

\section{Diverse roles of specific ionic conductances for fast-spiking in electrocytes}

Given the faster activation kinetics for eSlick compared to eSlack1 and eSlack2, the correlation of eSlick with EODf is consistent with the briefer APs required as EODf increases. Higher expression of $\mathrm{Na}^{+} / \mathrm{K}^{+}$ATPases at higher EODfs also is easily understood for higher frequency EODs, as increased rates of AP generation will require more rapid restoration of ionic gradients following each AP. Faster $\mathrm{K}^{+}$channels are required to achieve fast-spiking. However, they will also increase the overlap between $\mathrm{Na}^{+}$and $\mathrm{K}^{+}$currents, further magnifying the energetic costs of AP generation. If minimizing energy consumption is one constraint governing the types of ion channels expressed in neurons [47], neurons with faster $\mathrm{K}^{+}$channels should also express $\mathrm{Na}^{+}$channels with a faster inactivation speed in order to reduce the overlap between $\mathrm{Na}^{+}$and $\mathrm{K}^{+}$ currents. We have not yet determined the biophysical properties of $\mathrm{Na}_{\mathrm{v}} 1.4 \mathrm{a}$ and $\mathrm{Na}_{\mathrm{v}} 1.4 \mathrm{~b}$ in this system, but $\mathrm{Na}_{\mathrm{v}} 1.4 \mathrm{a}$ channels in weakly electric fish have numerous amino acid substitutions in regions associated with activation and inactivation [48].

The functional significance of scaling Kir6.2 expression levels with EODf is less clear. These channels are expressed at similar levels in EO and skeletal muscle unlike the other transcripts that scaled with EODf, and our computational simulations suggest that scaling Kir6.2 levels has only a minor role in maintaining integrity of the electrocyte AP waveform at high 


\section{Coregulation of ionic conductances - 30}

362 frequencies. One possibility is that Kir6.2 conductances are instead more important for

363 responding to the metabolic state of the electrocyte. In neural, cardiac, and endocrine systems,

364 Kir6.2 forms functional complexes with a sulphonylurea receptor (e.g. SUR1) belonging to the

365 ATP-binding cassette (ABC) superfamily [49, 50]. These Kir6.2-SUR1 complexes in other

366 systems are inhibited by physiological levels of ATP, increasing the channel's open probability

367 as intracellular concentrations of ATP fall and ultimately preventing AP initiation [51, 52].

The relationship between ATP availability and activity of the Kir6.2-SUR1 complex in

374 potentially exposes electrocytes to frequent changes in metabolic status. One appealing

375 hypothesis is that these $\mathrm{K}_{\text {АTP }}$ channel complexes may form an endogenous protective system to stabilize the cell's bioelectrical properties under metabolic stress as is the case in cardiac

377 myocytes [52]. Under this scenario higher levels of Kir6.2 would be required in higher-

378 frequency electrocytes to overcome the larger $\mathrm{Na}^{+}$conductances necessary for higher frequency 379 APs.

In an earlier study we characterized the electrophysiological properties of a $\mathrm{K}_{\mathrm{Na}}$ conductance in E. virescens electrocytes without distinguishing multiple channel isoforms [14].

382 In the present study, we discovered the presence of three $\mathrm{K}_{\mathrm{Na}}$ channel subunits expressed in 383 electrocytes, eSlack1, eSlack2 and eSlick. Among these eSlack1 and eSlack2 closely resemble 
sequence divergence from mammalian Slick including the loss of a conserved ATP binding motif. Mammalian Slick channels contain an ATP binding motif in the C-terminal tail and can be directly inhibited by intracellular ATP [25]. Whether eSlick is regulated by ATP remains a question for future research, but the absence of a conserved ATP binding motif in eSlick suggests that it is not.

It is noteworthy that E. virescens electrocytes terminate their APs with $\mathrm{K}_{\mathrm{Na}}$ channels whereas in all other electric fish where electrophysiology data are available and where EOD frequencies are much lower, electrocyte APs are terminated by Kv channels [14-17]. Fastspiking vertebrate cortical neurons maintain high firing frequencies and reduce the metabolic cost of AP generation to near the theoretical minimum by tuning the kinetics of $\mathrm{Na}^{+}$and $\mathrm{K}^{+}$ conductances to achieve rapid $\mathrm{Na}^{+}$current inactivation and delayed onset of a rapidly-activating $\mathrm{K}^{+}$conductance [55]. Similar mechanisms support high firing frequencies in brainstem auditory neurons [56]. In both cases, maintaining fast firing rates depends on voltage-gated $\mathrm{K}^{+}$ conductances from the $\mathrm{Kv} 3$ family of $\mathrm{K}^{+}$channels. In computational simulations from earlier work, however, we found evidence that $\mathrm{K}_{\mathrm{Na}}$ channels were necessary to support high-frequency APs in E. virescens electrocytes, while Kv3.1 channels were insufficient to maintain high firing frequencies [14].

Similar to mammalian $\mathrm{K}_{\mathrm{Na}}$ channels, the opening of eSlack1 channels requires elevations of intracellular $\mathrm{Na}^{+}$, whereas, eSlick channels' opening appears to be more dependent on intracellular levels of $\mathrm{Cl}^{-}$. These characteristics offer $\mathrm{K}_{\mathrm{Na}}$ channels several advantages over $\mathrm{Kv}$ channels in cells with high firing rates. The accumulation of intracellular $\mathrm{Na}^{+}$with high frequency stimulation may enhance activation of $\mathrm{K}_{\mathrm{Na}}$ channels which could in turn serve as a negative feedback mechanism for the increased activity of $\mathrm{Na}^{+}$channels. Additionally, $\mathrm{K}_{\mathrm{Na}}$ 
channels may play a protective role against the inhibition of $\mathrm{Na}^{+} / \mathrm{K}^{+}$ATPases under hypoxic conditions. The natural habitats of E. virescens include regions of low-oxygen waters and these of $\mathrm{Na}^{+} / \mathrm{K}^{+}$ATPases results in the increase of intracellular $\mathrm{Na}^{+}$concentrations, which might

412 enhance $\mathrm{K}_{\mathrm{Na}}$ channel activity to increase the cell's ability to react to metabolic stress arising

413 from hypoxia or dietary energy shortfalls [59].

\section{Multiple $\mathbf{K}_{\mathrm{Na}}$ channel subunits with distinctive roles}

417 are typically intermediate between the properties of homomeric channels for each subunit. In the

418 present study, eSlick currents were much faster than eSlack currents and therefore better suited

419 for higher frequency electrocytes. The positive correlation of eSlick expression with EODf

420 suggests two possibilities. One is that the ratio of eSlick homotetrameric channels to eSlack1

421 homotetrameric channels increases as EODf increases. A second possibility is that the ratio of

422 eSlick to eSlack subunits within heterotetramers increases with EOD frequency. All three KNa

423 channels in E. virescens electrocytes are expressed on the cells' anterior region, suggesting the

424 possibility that they form heterotetrameric $\mathrm{K}_{\mathrm{Na}}$ channels. Additionally, the failure of eSlack2

425 expressed alone to produce functional $\mathrm{K}_{\mathrm{Na}}$ channels strongly suggests that this subunit occurs

426 only within heterotetramers formed with eSlack1 and/or eSlick.

428 transcripts, Slack-A, Slack-B and Slack-M, which are regulated by alternative promoters and 429 differ in the residues in their N-terminus [30]. The N-terminus of Slack-B is necessary for the 
trafficking of Slick subunits into the plasma membrane and they can form heterotetrameric $\mathrm{K}_{\mathrm{Na}}$

432 eSlack1 have an unique N-terminus, which is not identical to the N-terminus of any known studies with immunoprecipitation are necessary to examine the interactions among the three $E$.

\section{Coregulation of ionic conductance densities as a general mechanism for fast-spiking cells}

$444[62,63]$. Interestingly, in these cases the relationships between EODf and channel expression

445 levels were linear, rather than exponential, suggesting the possibility that the much higher firing

446 frequencies of $E$. virescens necessitated not only a shift to a very different molecular class of

447 repolarizing $\mathrm{K}^{+}$conductances, but also an escalation to exponential scaling of those conductances.

It is now well known that excitable cells modify the expression patterns of ionic

450 conductances in order to maintain a particular functional state [64], but the cellular mechanisms 
452 of electrocytes in the present study. Do electrocytes respond to a given firing rate determined by

453 the pacemaker nucleus through a cell-autonomous mechanism that appropriately tunes the

454 expression levels of the necessary ion channels, or does some cell-extrinsic, perhaps endocrine,

455 mechanism regulate both pacemaker firing rate and electrocyte ion channel expression? The

456 contrasts between our present results and previous findings in S. macrurus highlight that

457 whatever mechanisms govern the scaling of ionic conductances in electrocytes, these

458 mechanisms are both surprisingly general (operating on different classes of ion channels and

459 with different scaling rules across taxa) and also very specific (targeting only specific ionic

460 conductance within the electrocyte, and assigning a specific scaling factor to each conductance).

461 An interesting question raised by the present findings is whether ionic conductance densities in

462 fast-spiking central neurons are actively tuned when their prevailing firing frequencies change

463 during development or in an experience-dependent manner. Recent reports of developmental

464 increases in metabolic efficiency for fast-spiking cortical neurons [55] suggest this may be the

465 case.

Understanding the mechanisms regulating of ion channel expression levels as firing rates

467 change is important not only in the context of electric sensory and communication signals in fish,

468 but also for understanding how the performance of fast-spiking cells is tuned and energy-

469 information tradeoffs are managed in other systems such as auditory processing networks, and

470 neural systems more generally. This is especially true because in both cases a tradeoff between

471 firing rates and metabolic cost appears to be a major force that shapes both the operational

472 properties and the functional limits of these systems [68]. In some cases, fast spiking cells

473 maintain the metabolic costs of AP generation near the theoretical minimum, even at very high

474 firing rates [55], while in other cases the metabolic costs of AP generation increase exponentially 
bioRxiv preprint doi: https://doi.org/10.1101/2021.03.08.434486; this version posted March 9, 2021. The copyright holder for this preprint (which was not certified by peer review) is the author/funder, who has granted bioRxiv a license to display the preprint in perpetuity. It is made available under aCC-BY-NC-ND 4.0 International license.

Coregulation of ionic conductances - 35

475 as firing rates increase [11]. Comparative analyses of these processes across different taxa and

476 different systems of excitable cells is an important step toward finding and understanding general

477 and potentially convergent mechanisms that maintain high-frequency activity in fast-spiking

478 cells and the rules that govern energy-information tradeoffs in bioelectric signaling systems. 


\section{Coregulation of ionic conductances - 36}

\section{MATERIALS AND METHODS}

480

481

482

483

484

485

486

487

488

489

490

491

492

493

494

495

496

497

498

499

\section{Animals and tissue harvesting}

E. virescens (glass knifefish) were obtained from tropical fish importers (Gunpowder Aquatics, Wimauma, FL), and housed in tanks in a recirculating aquarium system at $28 \pm 1^{\circ} \mathrm{C}$ with water conductivity 100-150 $\mathrm{S} / \mathrm{cm}$. They were kept under 12 hour light: 12 hour dark cycle and fed ad libitum with live blackworms. The EO tissue was harvested by cutting off $\sim 2 \mathrm{~cm}$ section of the tail and removing the overlying skin. Skeletal muscle tissue was dissected from the hypaxial muscle after fish were euthanized by immersion in $2 \%$ eugenol solution in aquarium water.

\section{EOD frequency measurements}

Fish were transferred to the EOD recording tank with two recording wires attached to the two opposite end walls and a ground wire located at one of the side walls. They were allowed to move freely while EODs were differentially amplified with a Cygnuys FLA-01 amplifier (Delaware Water Gap, PA) and EODf of the amplified signal was measured with a RadioShack digital multimeter set in frequency mode. To prevent the effects of temperature and water conductivity on the fish's EOD frequency, the recording tank was placed in the aquarium room and filled with water from the same aquarium system where the fish was kept. Representative EOD waveforms recorded from two fish are shown in Fig.1E. 


\section{Coregulation of ionic conductances - 37}

\section{Molecular Biology}

\section{$\underline{\text { Reagents }}$}

The pSP64 Poly(A) vector, ImProm-II ${ }^{\mathrm{TM}}$ Reverse Transcription System and GoTaq ${ }^{\circledR}$ DNA polymerase were purchased from Promega (Madison, WI). The RNA Clean \&

Concentrator $^{\mathrm{TM}}-5$ was purchased from Zymo Research (Irvine, CA). The SMARTer ${ }^{\circledR}$ RACE 5'/3' Kit was purchased from Clontech Laboratories, Inc. (Mountain View, CA). All other molecular biology reagents were purchased from Thermo Fisher Scientific (Waltham, MA).

\section{$\underline{\text { RNA and cDNA preparation }}$}

Tissues were homogenized using LabGEN 125 homogenizer (Cole-Parmer). Total RNA was extracted using TRIzol ${ }^{\circledR}$ reagent and purified using RNA Clean \& Concentrator ${ }^{\mathrm{TM}}-5$. Genomic DNA contamination was removed by incubating the total RNA with DNaseI at room temperature for at least 15 minutes. RNA quality was assessed by loading and running total RNA in a $1 \%$ agarose gel containing $0.5 \%$ bleach and SYBR ${ }^{\circledR}$ Green II RNA Gel Stain [69]. One microgram of EO total RNA was reverse transcribed to cDNA with oligo(dT) ${ }_{15}$ primer using ImProm-II ${ }^{\mathrm{TM}}$ Reverse Transcription System. The concentration of RNA and cDNA was measured by Qubit fluorometer 2.0 (Thermo Fisher Scientific).

\section{Cloning and sequencing of genes encoding E. virescens $\mathrm{K}_{\mathrm{Na}}$ channels}

cDNAs of interest were amplified by polymerase chain reaction (PCR) and 5'/3' rapid amplification of cDNA ends (RACE). All PCR and RACE products were initially analyzed on $1 \%$ agarose gels stained with $\mathrm{SYBR}^{\circledR}$ Safe DNA Gel Stain, purified and cloned into TOPO TA vector or pRACE vector. In each cloning, plasmids extracted from ten isolated individual 
521 colonies were sequenced by the Biology Core Molecular Lab at University of Oklahoma.

522 Sequence results were used as a query to search the rat protein database using the online NCBI

523 blastx tool to determine the molecular identity of amplified products [70].

524 eSlack1

A 500-bp fragment of eSlack1 was amplified by nested PCRs using Platinum ${ }^{\circledR}$ Taq High

526 Fidelity DNA Polymerase with two pairs of degenerate primers designed against the highly

527 conserved regions of published nucleotide sequences of Slack in other species (external primer

528 pair: forward 5'-ARAGYTTYACCTWYGCYKCCTTY-3' and reverse 5'- RYYTTYTSNBG

529 YARMAGRTGGCA-3'; internal primer pair: forward 5'- AYAARAARTAYGGWGTRTGT

530 HTG-3' and reverse 5'- GGMGAGCTSCCRATRTABGGMGA-3'). The thermocycler

531 conditions were $94^{\circ} \mathrm{C}$ for $2 \mathrm{~min}, 30$ cycles of $94^{\circ} \mathrm{C}$ for $30 \mathrm{sec}, 55^{\circ} \mathrm{C}$ for $30 \mathrm{sec}$, and $68^{\circ} \mathrm{C}$ for 3

$532 \mathrm{~min}$, followed by a final extension step of $68^{\circ} \mathrm{C}$ for $10 \mathrm{~min}$. The missing 5 'end of eSlack1 cDNA

533 was amplified by the following reactions: 1) A 1-kb fragment was amplified by a 5'RACE

534 reaction with a Slack degenerate primer (5'-GGMGAGCTSCCRATRTABGGMGA-3') and an

535 universal primer provided by the SMARTer ${ }^{\circledR}$ RACE 5'/3' Kit. 2) A 500-bp fragment was

536 amplified in a PCR with a forward degenerate primer (5'- GCCWTCBCAGCTSCTGGTGGT -

537 3') targeting the signature sequence of the $\mathrm{K}^{+}$selectivity filter and an eSlack1 specific reverse

538 primer (5'-GCAAAGTCCTTCACCGCCCA-3') designed from the partial cDNA fragment. 3) A

539 5'RACE PCR was carried out with an eSlack1 reverse primer (5'- TCACCTGACTGTCTGCCT

540 CACATGGAC -3') and the universal primer to amplify the start codon as well as the

541 5'untranslated region (UTR). The missing 3'end of eSlack1 including the stop codon and 3'UTR

542 was amplified by a 3'RACE reaction with an eSlack1 forward primer (5'- CTACCCGTCCACA 
GCATCATCACTAGC-3') and the universal primer. Sequences of the five eSlack1 fragments were aligned into a single contig (Geneious software, Biomatters Ltd, Auckland NZ). The fulllength cDNA of eSlack1 was amplified with a forward primer (5' - ATATATAAGCTTTCTT TATTACCGAAGGTGTCCCTCCG-3') derived from the 5'UTR and a reverse primer (5'TATATATCTAGAGTTTCGGTTGATCAGGTCAGTTTAAAC-3') derived from the 3'UTR. It

548 was cut at the HindIII and XbaI sites introduced in the primers and cloned into pSP64 Poly(A) 549 vector. Sequence of the insertion was confirmed to match the five overlapping PCR products. 550 eSlack1 cDNA contains 3495 nucleotides.

557 the entire region, and both of them share the highest homology with rat Slack (NCBI BLAST).

558 We next performed 5' and 3' RACE reactions to amplify the missing 5' and 3' ends. A $\sim 1.5-\mathrm{kb}$

559 product was amplified in the 5'RACE reaction with a gene specific reverse primer (5'-

GAGCTGACGCAGAGCACCACGTGTTT-3'), and a $\sim 5 \mathrm{~kb}$ product was amplified in the

562 CAACC-3'). Sequences of the three PCR products were aligned to a single contig using

563 Geneious. Full length eSlack2 cDNA was amplified with a forward primer (5'-ATATATGT

564 CGACCTTCTTTACAATGATGGGAC-3') targeting the 5'UTR and a reverse primer (5'- 
SalI and BamHI sites introduced to the primers and cloned into pSP64 Poly(A) vector. Sequence

567 of the insert corresponded to the consensus sequence of the aligned contig. eSlack2 is composed

568 of 3093 nucleotides.

569 eSlick

When amplifying the 3'end of eSlack2 with an eSlack2 specific forward primer (5'-

571

572

573

574

575

576

577

578

579

580

581

582

583

584

585

586

587 TCTGGTGGTGGTGGACAAGGAGAGC-3') and the universal primer, we detected a $\sim 2.5-\mathrm{kb}$ fragment. The RACE PCR product was cloned and sequenced as described. Nucleotide sequence was then blasted against rat protein database in NCBI, and shown to share the highest homology with rat Slick but not Slack. Then a 5'RACE PCR was performed to amplify the missing 5'end of the Slick transcript using a gene specific reverse primer (5'-ACGTCCTTATCCACAGAT CCTCCTCGG-3'). A 4-kb DNA fragment was amplified, cloned and sequenced. Sequences of the two DNA fragments were aligned to a single contig containing potential start codon at the 5' region and stop codon at the 3' end. Full-length eSlick cDNA was amplified with a forward primer (5' - ATATATGTCGACTTTAGAGGAACGCATACTTAGC-3') designed against the 5'UTR and a reverse primer (5'- TATATAGGATCCTAAGTAGTCAGATCAGTAGGGC-3') designed against the 3'UTR. It was cut at the Sall and BamHI sites introduced in the primers and cloned into pSP64 Poly(A) vector. eSlick cDNA contains 3510 nucleotides.

\section{$\underline{\text { Reverse transcription PCR analysis of gene expression in EO and muscle }}$}

To identify the expression patterns of target genes in EO and muscle, Reverse Transcription PCR was performed using GoTaq ${ }^{\circledR}$ DNA polymerase with one microliter EO or muscle cDNA. Genes of interest and their specific primers are listed in Table 1. Thermocycling conditions included $95^{\circ} \mathrm{C}$ for $2 \mathrm{~min}, 35$ cycles of $95^{\circ} \mathrm{C}$ for $30 \mathrm{sec}, 55^{\circ} \mathrm{C}$ for $30 \mathrm{sec}$, and $72^{\circ} \mathrm{C}$ for 


\section{Coregulation of ionic conductances - 41}

\section{1}

592

$1 \mathrm{~min}$ or 2 min (depending on the size of amplicons), and a final extension at $72^{\circ} \mathrm{C}$ for $5 \mathrm{~min}$.

After gel electrophoresis, PCR products were visualized using the Safe Imager ${ }^{\mathrm{TM}} 2.0$ (Thermo

Fisher Scientific). Gel images were taken with the same exposure time.

\begin{tabular}{|c|c|c|}
\hline \multicolumn{3}{|c|}{ Table 1. Primers used in reverse transcription PCR } \\
\hline Gene & \multicolumn{1}{|c|}{$\begin{array}{c}\text { Primers } \\
\text { (F: forward; R: reverse) }\end{array}$} & $\begin{array}{c}\text { Amplicon Size } \\
\text { (bp) }\end{array}$ \\
\hline$\beta$-actin & $\begin{array}{l}\text { F 5'-GTATTGTCACTAACTGGG-3' } \\
\text { R 5'-CATAGCTTTTCTCCAGAG-3' }\end{array}$ & 501 \\
\hline eSlack1 & $\begin{array}{l}\text { F 5'-TGTCTTCCACCTACGAGTGC-3' } \\
\text { R 5'-CCTCTCTGATCGACGAAACA-3' }\end{array}$ & 1157 \\
\hline eSlack2 & $\begin{array}{l}\text { F 5'-GGGTTCTGCAGATTCCTCTC-3' } \\
\text { R 5'-CCTCTGATGACGAGAACACG-3' }\end{array}$ & 1881 \\
\hline eSlick & $\begin{array}{l}\text { F 5'-ATACCCTGTTCGGGATTGAC-3' } \\
\text { R 5'-TGTGAACGCAGCTCTTATCC-3' }\end{array}$ & 1845 \\
\hline
\end{tabular}

$\underline{\text { Real-time PCR for mRNA quantitation in EO }}$

frequencies $(192 \mathrm{~Hz}, 202 \mathrm{~Hz}, 206 \mathrm{~Hz}, 229 \mathrm{~Hz}, 250 \mathrm{~Hz}, 300 \mathrm{~Hz}, 333 \mathrm{~Hz}, 350 \mathrm{~Hz}, 380 \mathrm{~Hz}, 395 \mathrm{~Hz}$, $426 \mathrm{~Hz}$ ) spanning the species' natural range was reverse transcribed to cDNA with oligo(dT) 15 primer using ImProm-II ${ }^{\mathrm{TM}}$ Reverse Transcription System. cDNA was diluted to $20 \mathrm{ng} / \mu \mathrm{l}$. Gene specific primers were designed using the GenScript online software to control the primer length $\sim 20$ bases, melting temperature $(\mathrm{Tm})$ in the range of $58-60^{\circ} \mathrm{C}$, and amplicon size $\sim 100 \mathrm{bp}$ (Table 2). Each reaction contained $100 \mathrm{ng}$ cDNA, 25ul 2× Power SYBR ${ }^{\circledR}$ Green Master Mix, $200 \mathrm{nM}$ of forward and reverse primer, and nuclease-free $\mathrm{H}_{2} \mathrm{O}$ to reach a total volume of $50 \mu$ l. Experiments were run in an Applied Biosystems 7500 Real-time PCR system using the default run method for Power SYBR ${ }^{\circledR}$ Green cDNA two step kit: hold at $95^{\circ} \mathrm{C}$ for $10 \mathrm{~min}$ and 40 cycles amplification (denature at $95^{\circ} \mathrm{C}$ for $15 \mathrm{sec}$, and anneal/extend at $60^{\circ} \mathrm{C}$ for $1 \mathrm{~min}$ ). Each sample has three technical replicates. The specificity of primers was assessed by both melt curve analysis and gel 
bioRxiv preprint doi: https://doi org/10.1101/2021.03.08.434486; this version posted March 9, 2021. The copyright holder for this preprint (which was not certified by peer review) is the author/funder, who has granted bioRxiv a license to display the preprint in perpetuity. It is made available under aCC-BY-NC-ND 4.0 International license.

Coregulation of ionic conductances - 42

605

606

607

608

609

610

611

612

613

614

615

5 quantification of gene expression using relative standard curve method. 105\%. Data were analyzed using Applied Biosystems 7500/7500 Fast software. Standard

\begin{tabular}{|c|c|c|}
\hline Gene & $\begin{array}{c}\text { Primers } \\
\text { (F: forward; R: reverse) }\end{array}$ & $\begin{array}{l}\text { Amplicon Size } \\
\text { (bp) }\end{array}$ \\
\hline$\beta$-actin & $\begin{array}{l}\text { F 5'-ATGAGGAAATCGCTGCTCTC-3' } \\
\text { R 5'-CCAACAATGGAAGGGAAGAC-3' }\end{array}$ & 103 \\
\hline $\mathrm{Na}_{\mathrm{v}} 1.4 \mathrm{a}$ & $\begin{array}{l}\text { F 5'-CAGCAAGGACAGAAAGGACA-3' } \\
\text { R 5'-CAATGGGCACATTCAGAACT-3' }\end{array}$ & 107 \\
\hline $\mathrm{Na}_{\mathrm{v}} 1.4 \mathrm{~b}$ & $\begin{array}{l}\text { F 5'-AAACTGAAGGAGGAGGAGGA-3' } \\
\text { R 5'-CTTTGGGTTCAGGCTCTTC-3' }\end{array}$ & 98 \\
\hline Kir6.2 & $\begin{array}{l}\text { F 5'-TGTTACCGACATCCACTCGT-3' } \\
\text { R 5'-GCAGACACGCATTCTTCTGT-3' }\end{array}$ & 105 \\
\hline $\mathrm{Na}^{+} / \mathrm{K}^{+}$ATPase & $\begin{array}{l}\text { F 5'-CAGGAGACCTGGTGGAGATT-3' } \\
\text { R 5'-ACTCTCCGGTCAGAGAGGAA-3' }\end{array}$ & 105 \\
\hline eSlack1 & $\begin{array}{l}\text { F 5'-AAGAGCATGCACTGGACAAG-3' } \\
\text { R 5'-CCTCTCTGATCGACGAAACA-3' }\end{array}$ & 108 \\
\hline eSlack2 & $\begin{array}{l}\text { F 5'-GATCCCAATCGGACTGTACC-3' } \\
\text { R 5'-CGCACGAGGAACATCAAATA-3' }\end{array}$ & 93 \\
\hline eSlick & $\begin{array}{l}\text { F 5'-ATACCCTGTTCGGGATTGAC-3' } \\
\text { R 5'- GGCATATGACTGCAACAACC-3' }\end{array}$ & 93 \\
\hline
\end{tabular}

616

electrophoresis of qPCR product. The expression level of all target genes were normalized to the endogenous control $\beta$-actin. EO cDNA from fish with the lowest EOD frequency $(192 \mathrm{~Hz}) \mathrm{was}$ used as the calibrator sample. Reactions without cDNA template were performed as negative controls. All negative controls showed no amplification or amplification starting more than eight cycles later than the reactions with cDNA template. In each experimental run, the standard curve was generated using 500, 100, 20, 4, $0.8 \mathrm{ng}$ EO cDNA from a fish with 202Hz EOD frequency. All target genes and $\beta$-actin had standard curves with $\mathrm{R}^{2}>0.97$. The slopes of standard curves were used to estimate the amplification efficiencies, which were in the range between $95 \%$ and deviations were calculated by following the Applied Biosystems guide to perform relative 


\section{Coregulation of ionic conductances - 43}

618

619

620

621

622

623

624

625

626

627

628

629

630

631

632

633

634

635

636

637

638

639

640

E. virescens Slack1, Slack2, and Slick cDNA sequences were translated and aligned with protein sequences of the SLO family channels in nematode, zebrafish, mouse, rat and human using ClustalW. Then the phylogenetic relationship was analyzed using the Geneious software (version 7.1.7). The consensus tree was obtained by using neighbor-joining method, Jukes Cantor amino acid substitution model and resampled 1000 times with Bootstrapping method.

Human voltage gated $\mathrm{K}^{+}$channel subfamily A member 1 (hKv1.1) was included as the outgroup. Channels included in the phylogenetic analysis are Caenorhabditis elegans Slolchannel (NCBI accession number: Q95V25); Danio rerio Slo1 channel (NP_001139072); Mus musculus Slo1 channel (NP_001240287); Rattus norvegicus Slo1 channel (NP_114016); Homo sapiens Slo1 channel (AAI44497); Caenorhabditis elegans Slo2 channel (AAD51350); Danio rerio Slack channel (XP_009293403); Danio rerio Slick channel (XP_017214614); Mus musculus Slack channel (NP_780671); Mus musculus Slick channel (NP_001074496); Rattus norvegicus Slack channel (NP_068625); Rattus norvegicus Slick channel (NP_942057); Homo sapiens Slack channel (NP_065873); Homo sapiens Slick channel (NP_940905); Mus musculus Slo3 channel (O54982); Homo sapiens Slo3 channel (NP_001027006); Homo sapiens Kv1.1 channel (NP_000208).

\section{Expression of recombinant $K_{\mathrm{Na}}$ channels in electrocytes}

We constructed recombinant eSlack1, eSlack2 and eSlick channels tagged with the red fluorescent protein (mCherry) at their N-terminus. mCherry was PCR amplified from u-mCherry (a gift from Scott Gradia; Addgene plasmid \# 29769). The polylinker sequences between ion channels and mCherry are GGSGGGSGGSGS for eSlack1/ eSlick, and GGSGGGSG for eSlack2 [40, 41]. mCherry-eSlack1, mCherry-eSlack2 and mCherry-eSlick was assembled and cloned into pOX vector using the NEBuilder ${ }^{\circledR}$ HiFi DNA Assembly Master Mix (New England 
641 Biolabs ${ }^{\circledR}$ Inc.), then subcloned into pmaxCloning ${ }^{\mathrm{TM}}$ vector (Lonza). Prior to EO injection, the

642 fish were anesthetized by exposing them to $0.01 \%$ clove oil until losing equilibrium but still

643 maintaining opercular beating ( $<2 \mathrm{~min}$ total). A single $25 \mu \mathrm{l}$ bolus of $5 \mu \mathrm{g} / \mu \mathrm{l}$ plasmid in 150

$644 \mathrm{mM} \mathrm{KCl}$ was injected into the fish's EO in the tail using a microliter syringe. The injected fish

645 was transferred to a bucket containing aerated water from its home tank and monitored for

646 recovery, then transferred back to its home tank after full recovery. The expression of mCherry

647 tagged ion channels was examined at the $10^{\text {th }}$ day after injection using epifluorescence and

648 confocal microscopy.

Image acquisition

To examine the expression of mCherry-eSlack1, mCherry-eSlack2 and mCherry-eSlick in

651 electrocytes, we harvested the EO using the same procedure as described earlier [37]. Live

652 electrocytes were first examined on a Zeiss Apotome.2 microscope with a X5/0.16NA dry

653 objective and processed by Zeiss AxioVision Rel.4.8.2. Structured illumination was used to

654 create optical sections of the sample. Then we used LeicaTCS SP8 laser scanning confocal

655 microscope with a X25/0.95NA dipping objective to acquire high resolution images. mCherry

656 was excited by a 561-nm laser line and autofluorescence of electrocyte was excited by a 488-nm

657 laser line [37]. The images were acquired as serial sections and processed by the software Leica

658 Application Suite advanced Fluorescence (LAS AF) 3.3.0.10134. Electrocytes without

659 expressing mcherry tagged eSlack/Slick subunits were used as control and imaged under the

660 same settings. 


\section{Coregulation of ionic conductances - 45}

663 dry objective. Brightness and contrast of all images were adjusted using ImageJ for 64-bit

664 Windows (version 1.51s; National Institute of Health).

665

666

667

668

669

670

671

672

673

674

675

676

677

678

679

680

681

682

683

684

\section{Electrophysiology}

eSlack/Slick cDNA was subcloned into pOX vector (a generous gift of Dr. Lawrence B.

Salkoff, Washington University, St. Louis, USA). In vitro transcribed RNA (cRNA) was

prepared using the mMESSAGE mMACHINE ${ }^{\mathrm{TM}} \mathrm{T} 3$ Transcription Kit (Thermo Fisher

Scientific). We used an Agilent 2100 Bioanalyzer to examine the quality and concentration of

cRNA. Defolliculated $X$. laevis oocytes in stage VI were obtained from Ecocyte Bioscience

(Austin, TX) and incubated in modified Barth's saline containing the following in $\mathrm{mM}: \mathrm{NaCl} 88$,

$\mathrm{KCl} 1, \mathrm{NaHCO}_{3} 2.4, \mathrm{MgSO}_{4} 0.82, \mathrm{Ca}(\mathrm{NO} 3)_{2} \cdot 4 \mathrm{H}_{2} \mathrm{O} 0.33, \mathrm{CaCl}_{2} \cdot 2 \mathrm{H}_{2} \mathrm{O} 0.41, \mathrm{HEPES} 5$,

$\mathrm{CH} 3 \mathrm{COCOONa} 2.5$, and $50 \mu \mathrm{g} / \mathrm{ml}$ gentamycin at $\mathrm{pH}$ 7.5. Oocytes were injected with $46 \mathrm{nl}$ of

nuclease-free water containing $\sim 80 \mathrm{ng}$ of cRNA and analyzed 4 to 5 days post injection.

Whole cell currents from oocytes were recorded using a standard two electrode configuration [14], with an Axoclamp 900 amplifier controlled by a Digidata 1440 interface and pCLAMP10 software (Molecular Devices, Sunnyvale, CA). Data were sampled at $100 \mathrm{kHz}$ and filtered at $10 \mathrm{kHz}$. Electrodes were pulled from $1.2 \mathrm{~mm}$ o.d. thin-wall borosilicate glass tubing, filled with $2 \mathrm{M} \mathrm{NaCl}$ or $\mathrm{KCl}$ and had resistances of 0.5-1.2 $\mathrm{M} \Omega$. Oocytes were incubated in ND96 saline (in mM: $96 \mathrm{NaCl}, 2 \mathrm{KCl}, 1 \mathrm{MgCl}_{2}, 1.8 \mathrm{CaCl}_{2} \cdot 2 \mathrm{H}_{2} \mathrm{O}$ and $5 \mathrm{HEPES}$, pH to 7.5). To measure channel activation, oocytes were held at $-90 \mathrm{mV}$, then depolarized by $400 \mathrm{~ms}$ voltage steps ranging from $-90 \mathrm{mV}$ to $+80 \mathrm{mV}$ in $10 \mathrm{mV}$ increments every $5 \mathrm{~s}$. In some experiments, cells were depolarized by a $500 \mathrm{~ms}$ pulse to $+20 \mathrm{mV}$ from a holding potential of $-90 \mathrm{mV}$ every 10 s to examine the effects of $\mathrm{NaCl}$ and $\mathrm{KCl}$ on the amplitude of whole-cell currents. The 
685

686

687

688

689

690

691

692

693

694

695

696

697

698

699

700

701

702

703

704

705

activation $\tau$ for eSlack and eSlick currents was estimated using the Clampfit fitting functions.

Current traces from the start point to the peak point just before the plateau stage were fitted to a standard single-term exponential growth function. The time required to reach $62.8 \%$ of the final value was calculated as the activation $\tau$.

\section{Computational Simulations}

We modeled E. virescens electrocyte APs with a simplified version of our earlier

electrocyte simulations [37]. Briefly, the electrocyte was simulated with the Hodgkin-Huxley

formalism as a three-compartment cell with an active posterior compartment, a passive central compartment, and an active anterior compartment. Simulated cholinergic synaptic current was

applied only to the posterior compartment and the frequency of the synaptic inputs was varied to elicit trains of simulated APs with frequencies of $150 \mathrm{~Hz}$ to $425 \mathrm{~Hz}$ in $25 \mathrm{~Hz}$ increments.

The capacitances for the posterior, central, and anterior compartments were $48.0 \mathrm{nF}, 18$

$\mathrm{nF}$, and $18 \mathrm{nF}$, respectively, based on surface area measurements from high-resolution confocal

3D reconstructions of single electrocytes. Differential equations integrated via Euler's method

were coded in Matlab (Mathworks, Inc. Natick MA) with integration time steps of $5 \times 10^{-8} \mathrm{sec}$.

The passive central compartment's current balance equation included only passive leak ( $\left.\mathrm{I}_{\mathrm{L}}\right)$ fixed at $5 \mu \mathrm{S}$, and coupling to the two adjoining active compartments as in Equation 1

$$
C_{m} \frac{d V_{c}}{d t}=-I_{L}+g_{w}\left(V_{a}-V_{c}\right)+g_{w}\left(V_{p}-V_{c}\right)
$$

where $g_{w}$ is the coupling conductance, fixed at $3 \mu \mathrm{S}$. The current balance equation for the posterior compartment was

$$
C_{m} \frac{\mathrm{dV}_{\mathrm{p}}}{\mathrm{dt}}=I_{S y n}(t)-\mathrm{I}_{\mathrm{Na}}-\mathrm{I}_{\mathrm{L}}+g_{w}\left(V_{c}-V_{p}\right)
$$


and the current balance equation for the anterior compartment was

707

$$
C_{m} \frac{\mathrm{dV}_{\mathrm{a}}}{\mathrm{dt}}=-\mathrm{I}_{\mathrm{KNa}}-\mathrm{I}_{\mathrm{R}}-\mathrm{I}_{\mathrm{L}}+g_{w}\left(V_{c}-V_{a}\right)
$$

708

709

710

711

712

721

where ISyn represents synaptic current, $I_{N a}$ is the voltage-gated $\mathrm{Na}^{+}$current, IKNa is the $\mathrm{Na}^{+}-$ activated $\mathrm{K}^{+}$current, $\mathrm{I}_{\mathrm{R}}$ is the inward rectifier $\mathrm{K}^{+}$current, and $\mathrm{g}_{\mathrm{w}}$ is the coupling current to the adjacent compartment. For all three compartments the leak current, IL, was given by Equation 4, where $\bar{g}_{\mathrm{L}}$ was $10 \mu \mathrm{S}, 5 \mu \mathrm{S}$, and $10 \mu \mathrm{S}$ for the posterior, central, and anterior compartments, respectively.

$$
I_{L}=\bar{g}_{\mathrm{L}}(\mathrm{V}+95)
$$

The posterior-compartment synaptic current, Isyn, was given by Equation 5

$$
I_{\text {Syn }}=\bar{g}_{\text {Syn }} g_{\text {Syn }(t)}\left(V_{p}-15\right)
$$

with $\bar{g}_{S y n}$ fixed at $600 \mu$ s for all models and where the time series gSyn(t) was a series of alpha waveforms generated using the discrete time equation [71]:

$$
g_{\operatorname{Syn}(n+2)}=2\left(1-\frac{T}{\tau}\right) g_{\operatorname{Syn}(n+1)}-\left(1-\frac{T}{\tau}\right)^{2} g_{\operatorname{Syn}(n)}+\left(\frac{T}{\tau}\right)^{2} x(n)
$$

For this equation $T$ is the integration time step and $\tau$ is the time constant. The binary series $x(n)$ specified the onset times of the synaptic inputs, and the resulting time-series $g_{S y n}(n)$ was normalized such that $0 \leq g_{S y n}(n) \leq 1$.

The voltage-dependent currents $\mathrm{I}_{\mathrm{Na}}, \mathrm{IK}_{\mathrm{Na}}$, and $\mathrm{I}_{\mathrm{R}}$ were given by Equations 7 - 9:

$$
I_{N a}=\bar{g}_{N a} m^{3} h\left(V_{p}-52\right)
$$

$$
I_{K N a}=\bar{g}_{K N a} n^{4} s^{4}\left(V_{a}+95\right)
$$




$$
I_{R}=\bar{g}_{R}\left(\frac{1}{1+\exp (0.22(V a+85))}\right)\left(V_{a}+95\right)
$$

726 The baseline values of $\bar{g}_{N a}, \bar{g}_{K N a}$, and $\bar{g}_{R}$, were $2300 \mu \mathrm{S}, 2000 \mu \mathrm{S}$, and $125 \mu \mathrm{S}$, respectively.

727 The gating variables $m, h$, and $n$ in Equations 7 and 8 evolved in a voltage-dependent manner or $\left.V_{a}\right)$ and $j=m, h$, or $n$

$$
\frac{d j}{d t}=\frac{j_{\infty}(V)-j}{\tau_{j}(V)}
$$

731

732

733

734

735

736

737

738
The voltage-dependent values of $j_{\infty}$ in Equation 10 were determined according to Equations 1113 for $j=m, h$, or $n$, respectively:

$$
m_{\infty}=\frac{1}{1+\exp \left(\frac{-37.46-V p}{8.530}\right)}
$$

$$
h_{\infty}=\frac{1}{1+\exp \left(\frac{-48.42-V p}{-4.194}\right)}
$$

$$
n_{\infty}=1.494 \times \exp \left(0.00028 \times V_{a}\right)+\left(-0.7351 \times \exp \left(-0.00681 \times V_{a}\right)\right)
$$

and $\tau_{j}$ was given by Equations 14,15 , and 16 for $j=m$, $h$, or $n$, respectively.

$$
\tau_{m}=\frac{0.2286}{1+\left(\frac{V_{p}+83.9}{24.97}\right)^{2}}+0.6128
$$

$$
\tau_{h}=1.653 \times \exp \left(-0.5 \times\left(\frac{V_{p}+120}{44.54}\right)^{2}\right)+0.060
$$

$$
\tau_{n}=0.4654 \times \exp \left(-\left(\frac{V_{a}+88.73}{37.33}\right)^{2}\right)+4.965 \times \exp \left(-\left(\frac{V_{a}+5478}{4833}\right)^{2}\right)
$$


740 All parameter values in Equation 9 and Equations 11-16 were determined by least-squares best

741 fits to experimental data for $\mathrm{I}_{\mathrm{KNa}}$ from the present study for $j=n$ and were determined by least-

742 squares best fits to previous experimental recordings of $\mathrm{I}_{\mathrm{Na}}$ in E. virescens electrocytes [14] for $j$

$743=m$ and $h$. We previously modeled the $\mathrm{Na}^{+}$-dependence of gKNa with the gating variable, $s$, which

744 is determined by the $\mathrm{Na}^{+}$concentration in the bulk cytoplasm in the anterior compartment [37].

745 In those simulations, however, there were no significant changers in $\mathrm{Na}^{+}$concentration. We

746 therefore did not model changes in $\mathrm{Na}^{+}$concentrations in the present model and the $\mathrm{Na}+$ gating

747 variable $s$ was therefore fixed at 0.7895 , in accordance with the fixed anterior compartment $\mathrm{Na}^{+}$

748 concentration of $15 \mathrm{mM}$.

750 models, and held constant in other models. Values of these parameters were given by Equations

751 17-19, where $x$ denotes AP frequency:

752

753

754

$$
\bar{g}_{N a}=\left(0.264 e^{0.0057 x}\right) \times 2300+700
$$

The base and exponential parameters in Equations 17-19 are based on RNA expression data from

757 where the AP duration was one-half of the interspike interval at an AP frequency where $x=150$

758 Hz. In models where values of $\bar{g}_{N a}, \bar{g}_{K N a}$, and/or $\bar{g}_{R}$, were held constant, the value of x was 
bioRxiv preprint doi: https://doi.org/10.1101/2021.03.08.434486; this version posted March 9, 2021. The copyright holder for this preprint (which was not certified by peer review) is the author/funder, who has granted bioRxiv a license to display the preprint in perpetuity. It is made available under aCC-BY-NC-ND 4.0 International license.

Coregulation of ionic conductances - 50

To determine the required activity of the Na,K-ATPase to restore ionic gradients between

761 APs, we calculated total $\mathrm{Na}^{+}$entry via the voltage-gated $\mathrm{Na}+$ conductance during each $\mathrm{AP}$ as

762 moles of $\mathrm{Na}^{+}$by multiplying the integrated $\mathrm{Na}^{+}$current (in $\mathrm{nA}^{*} \mathrm{~ms}$ ) by $10^{-12}$ to yield Coulombs of

763 charge, then dividing by the elementary charge on a monovalent cation, $e$, to yield the number of

$764 \mathrm{Na}^{+}$ions, then dividing by Avogadro's constant, $L$, to yield moles of $\mathrm{Na}^{+}$. 
bioRxiv preprint doi: https://doi.org/10.1101/2021.03.08.434486; this version posted March 9, 2021. The copyright holder for this preprint (which was not certified by peer review) is the author/funder, who has granted bioRxiv a license to display the preprint in perpetuity. It is made available under aCC-BY-NC-ND 4.0 International license.

Coregulation of ionic conductances - 51

\section{ACKNOWLEDGEMENTS}

The authors declare no conflict of interest and no competing financial interests. Financial

767 support and equipment were provided by NSF grants IOS1350753, and IOS 1644965 (M.R.M.).

768 This research was also supported in part by a grant from the Research Council of the University

769 of Oklahoma Norman Campus. We thank in particular Lawrence Salkoff for the gift of pOX

770 vector, David McCauley for valuable suggestions on experimental design, and Tingting Gu for

771 imaging assistance. Thanks to Austin McCauley and Shannon Wiser for fish care, Tian Yuan and

772 Mehrnoush Nourbakhsh for help in molecular cloning, Rosemary Knapp for use of her cryostat,

773 and J.P. Masly for use of his microscope. 


\section{Coregulation of ionic conductances - 52}

\section{REFERENCES}

775 1. Niven JE. Neuronal energy consumption: biophysics, efficiency and evolution. Curr Opin

776 Neurobiol. 2016;41:129-35. doi: dx.doi.org/10.1016/j.conb.2016.09.004.

7772 Niven JE, Laughlin SB. Energy limitation as a selective pressure on the evolution of 778 sensory systems. J Exp Biol. 2008;211(Pt 11):1792-804. Epub 2008/05/21. doi: 211/11/1792 779 [pii]10.1242/jeb.017574. PubMed PMID: 18490395.

$780 \quad 3 . \quad$ Buzsaki G, Draguhn A. Neuronal oscillations in cortical networks. Science.

781 2004;304(5679):1926-9. Epub 2004/06/26. doi: 10.1126/science.1099745. PubMed PMID:

78215218136.

783 4. Kann O, Papageorgiou IE, Draguhn A. Highly energized inhibitory interneurons are a 784 central element for information processing in cortical networks. J Cereb Blood Flow Metab.

785 2014;34(8):1270-82. Epub 2014/06/05. doi: 10.1038/jcbfm.2014.104. PubMed PMID:

786 24896567; PubMed Central PMCID: PMCPMC4126088.

787 5. $\mathrm{Hu} \mathrm{H}$, Gan J, Jonas P. Interneurons. Fast-spiking, parvalbumin(+) GABAergic

788 interneurons: from cellular design to microcircuit function. Science. 2014;345(6196):1255263.

789 Epub 2014/08/02. doi: 10.1126/science.1255263. PubMed PMID: 25082707.

790 6. Carter BC, Bean BP. Sodium entry during action potentials of mammalian neurons:

791 Incomplete inactivation and reduced metabolic efficiency in fast-spiking neurons. Neuron.

792 2009;64(6):898-909. Epub 2010/01/13. doi: 10.1016/j.neuron.2009.12.011. PubMed PMID:

793 20064395; PubMed Central PMCID: PMC2810867.

794 7. Hopkins CD. Electric communication: functions in the social behavior of Eigenmannia 795 virescens. Behaviour. 1974:270-305. 
796 8. Scheich H. Neural basis of communication in the high frequency electric fish,

797 Eigenmannia virescens (jamming avoidance response). Journal of comparative physiology.

$798 \quad 1977 ; 113(2): 181-206$.

799 9. Helfman G, Collette BB, Facey DE, Bowen BW. The diversity of fishes: biology, 800 evolution, and ecology: John Wiley \& Sons; 2009.

801 10. Stoddard PK, Markham MR. Signal cloaking by electric fish. Bioscience.

802 $2008 ; 58(5): 415-25$.

803 11. Lewis JE, Gilmour KM, Moorhead MJ, Perry SF, Markham MR. Action potential 804 energetics at the organismal level reveal a trade-off in efficiency at high firing rates. J Neurosci. 2014;34(1):197-201. doi: 10.1523/jneurosci.3180-13.2014.

806 12. Wang B, Ke W, Guang J, Chen G, Yin L, Deng S, et al. Firing Frequency Maxima of 807 Fast-Spiking Neurons in Human, Monkey, and Mouse Neocortex. Front Cell Neurosci. 808 2016;10:239. Epub 2016/11/03. doi: 10.3389/fncel.2016.00239. PubMed PMID: 27803650; PubMed Central PMCID: PMCPMC5067378.

810 13. Wu SH, Kelly JB. Response of neurons in the lateral superior olive and medial nucleus of 811 the trapezoid body to repetitive stimulation: intracellular and extracellular recordings from 812 mouse brain slice. Hear Res. 1993;68(2):189-201. Epub 1993/08/01. doi: 10.1016/0378813 5955(93)90123-i. PubMed PMID: 8407605.

814 14. Markham MR, Kaczmarek LK, Zakon HH. A sodium-activated potassium channel 815 supports high-frequency firing and reduces energetic costs during rapid modulations of action 816 potential amplitude. Journal of neurophysiology. 2013;109(7):1713-23.

817 15. Ferrari MB, Zakon HH. Conductances contributing to the action potential of Sternopygus 818 electrocytes. J Comp Physiol, A. 1993;173(3):281-92. PubMed Central PMCID: PMC0008. 
819 16. Sierra F, Comas V, Buno W, Macadar O. Voltage-gated potassium conductances in

820 Gymnotus electrocytes. Neuroscience. 2007;145(2):453-63. Epub 2007/01/16. doi:

821 10.1016/j.neuroscience.2006.12.002. PubMed PMID: 17222982.

822 17. Markham MR, Zakon HH. Ionic mechanisms of microsecond-scale spike timing in single

823 cells. J Neurosci. 2014;34(19):6668-78. doi: 10.1523/jneurosci.0615-14.2014.

824 18. Bean BP. The action potential in mammalian central neurons. Nature Reviews

825 Neuroscience. 2007;8(6):451-65.

826 19. Coetzee WA, Amarillo Y, Chiu J, Chow A, Lau D, McCormack T, et al. Molecular

827 diversity of K+ channels. Annals of the New York Academy of Sciences. 1999;868(1):233-55.

828 20. Erisir A, Lau D, Rudy B, Leonard C. Function of specific K+ channels in sustained high-

829 frequency firing of fast-spiking neocortical interneurons. Journal of neurophysiology.

$830 \quad 1999 ; 82(5): 2476-89$.

831 21. Few WP, Zakon HH. Sex differences in and hormonal regulation of Kv1 potassium

832 channel gene expression in the electric organ: molecular control of a social signal.

833 Developmental neurobiology. 2007;67(5):535-49.

834 22. Kaczmarek LK, Bhattacharjee A, Desai R, Gan L, Song P, von Hehn CA, et al.

835 Regulation of the timing of MNTB neurons by short-term and long-term modulation of

836 potassium channels. Hearing research. 2005;206(1):133-45.

837 23. Shao LR, Halvorsrud R, Borg - Graham L, Storm JF. The role of BK - type Ca2+ -

838 dependent $\mathrm{K}+$ channels in spike broadening during repetitive firing in rat hippocampal pyramidal

839 cells. The Journal of Physiology. 1999;521(1):135-46. 
840 24. Joiner WJ, Tang MD, Wang L-Y, Dworetzky SI, Boissard CG, Gan L, et al. Formation of

841 intermediate-conductance calcium-activated potassium channels by interaction of Slack and Slo

842 subunits. Nature neuroscience. 1998;1(6):462-9.

843 25. Bhattacharjee A, Joiner WJ, Wu M, Yang Y, Sigworth FJ, Kaczmarek LK. Slick (Slo2.

844 1), a rapidly-gating sodium-activated potassium channel inhibited by ATP. The Journal of

845 neuroscience. 2003;23(37):11681-91.

846 26. Zakon HH, Lu Y, Zwickl DJ, Hillis DM. Sodium channel genes and the evolution of

847 diversity in communication signals of electric fishes: convergent molecular evolution.

848 Proceedings of the National Academy of Sciences of the United States of America.

$8492006 ; 103(10): 3675-80$.

850 27. Bennett MV. Comparative physiology: electric organs. Annual review of physiology.

$851 \quad 1970 ; 32(1): 471-528$.

852 28. Gallant JR, Traeger LL, Volkening JD, Moffett H, Chen P-H, Novina CD, et al. Genomic

853 basis for the convergent evolution of electric organs. Science. 2014;344(6191):1522-5.

854 29. Unguez GA, Zakon HH. Reexpression of myogenic proteins in mature electric organ

855 after removal of neural input. The Journal of neuroscience. 1998;18(23):9924-35.

856 30. Brown MR, Kronengold J, Gazula VR, Spilianakis CG, Flavell RA, Von Hehn CA, et al.

857 Amino - termini isoforms of the Slack K+ channel, regulated by alternative promoters,

858 differentially modulate rhythmic firing and adaptation. The Journal of physiology.

$859 \quad 2008 ; 586(21): 5161-79$.

860 31. Hite RK, Yuan P, Li Z, Hsuing Y, Walz T, MacKinnon R. Cryo-electron microscopy

861 structure of the Slo2. 2 Na+-activated K+ channel. Nature. 2015;527(7577):198-203. 


\section{Coregulation of ionic conductances - 56}

862 32. Hofmann K, Stoffel W. TMbase-A database of membrane spanning protein segments.

8631993.

864 33. Krogh A, Larsson B, Von Heijne G, Sonnhammer EL. Predicting transmembrane protein 865 topology with a hidden Markov model: application to complete genomes. Journal of molecular 866 biology. 2001;305(3):567-80.

867 34. Zhang Z, Rosenhouse-Dantsker A, Tang Q-Y, Noskov S, Logothetis DE. The RCK2 868 domain uses a coordination site present in Kir channels to confer sodium sensitivity to Slo2. 2 869 channels. The Journal of Neuroscience. 2010;30(22):7554-62.

870 35. Thomson SJ, Angela H, Sanguinetti MC. Identification of the Intracellular Na+ Sensor in

871 Slo2. 1 Potassium Channels. Journal of Biological Chemistry. 2015:jbc. M115. 653089.

872 36. Walker JE, Saraste M, Runswick MJ, Gay NJ. Distantly related sequences in the alpha873 and beta-subunits of ATP synthase, myosin, kinases and other ATP-requiring enzymes and a 874 common nucleotide binding fold. The EMBO journal. 1982;1(8):945.

875 37. Ban Y, Smith BE, Markham MR, Ban Y. A highly-polarized excitable cell separates 876 sodium channels from sodium-activated potassium channels by more than a millimeter. Journal 877 of neurophysiology. 2015:jn. 00475.2014.

878 38. Ban Y, Smith BE, Markham MR. A highly polarized excitable cell separates sodium 879 channels from sodium-activated potassium channels by more than a millimeter. J Neurophysiol. $880 \quad 2015 ; 114(1): 520-30$.

881 39. Sudha PM, Low S, Kwang J, Gong Z. Multiple tissue transformation in adult zebrafish by 882 gene gun bombardment and muscular injection of naked DNA. Marine Biotechnology. $883 \quad 2001 ; 3(2): 119-25$. 
884

885

886

887

888

889

890

891

892

893

894

895

896

897

898

899

900

901

902

903

904

905

40. Shi S-H, Hayashi Y, Petralia RS, Zaman SH, Wenthold RJ, Svoboda K, et al. Rapid spine delivery and redistribution of AMPA receptors after synaptic NMDA receptor activation.

Science. 1999;284(5421):1811-6.

41. Perestenko PV, Henley JM. 7 Visualization of AMPAR Trafficking and Surface Expression. The Dynamic Synapse: Molecular Methods in Ionotropic Receptor Biology. 2006:119.

42. Nuwer MO, Picchione KE, Bhattacharjee A. PKA-induced internalization of slack KNa channels produces dorsal root ganglion neuron hyperexcitability. The Journal of Neuroscience. 2010;30(42):14165-72.

43. Cristofori-Armstrong B, Soh MS, Talwar S, Brown DL, Griffin JD, Dekan Z, et al.

Xenopus borealis as an alternative source of oocytes for biophysical and pharmacological studies of neuronal ion channels. Scientific reports. 2015;5:14763.

44. Egan T, Dagan D, Kupper J, Levitan I. Properties and rundown of sodium-activated potassium channels in rat olfactory bulb neurons. J Neurosci. 1992;12(5):1964-76.

45. Garg P, Gardner A, Garg V, Sanguinetti MC. Structural basis of ion permeation gating in Slo2. $1 \mathrm{~K}+$ channels. The Journal of general physiology. 2013;142(5):523-42.

46. Weber W-M. Ion currents of Xenopus laevis oocytes: state of the art. Biochimica et Biophysica Acta (BBA)-Biomembranes. 1999;1421(2):213-33.

47. Hasenstaub A, Otte S, Callaway E, Sejnowski TJ. Metabolic cost as a unifying principle governing neuronal biophysics. Proc Natl Acad Sci U S A. 2010;107(27):12329-34. Epub 2010/07/10. doi: 10.1073/pnas.0914886107. PubMed PMID: 20616090; PubMed Central PMCID: PMC2901447. 
906

907

908

909

910

911

912

913

914

915

916

917

918

919

920

921

922

923

924

925

926

927

928

48. Arnegard ME, Zwick1 DJ, Lu Y, Zakon HH. Old gene duplication facilitates origin and diversification of an innovative communication system--twice. Proc Natl Acad Sci USA. 2010;107(51):22172-7. Epub 2010/12/04. doi: 10.1073/pnas.1011803107. PubMed PMID: 21127261 ; PubMed Central PMCID: PMC3009798.

49. Sakura H, Ammala C, Smith PA, Gribble FM, Ashcroft FM. Cloning and functional expression of the cDNA encoding a novel ATP-sensitive potassium channel subunit expressed in pancreatic beta-cells, brain, heart and skeletal muscle. FEBS Lett. 1995;377(3):338-44. Epub 1995/12/27. doi: 10.1016/0014-5793(95)01369-5. PubMed PMID: 8549751.

50. Ashcroft FM, Gribble FM. Correlating structure and function in ATP-sensitive K+ channels. Trends Neurosci. 1998;21(7):288-94. Epub 1998/07/31. PubMed PMID: 9683320. 51. Inagaki N, Tsuura Y, Namba N, Masuda K, Gonoi T, Horie M, et al. Cloning and functional characterization of a novel ATP-sensitive potassium channel ubiquitously expressed in rat tissues, including pancreatic islets, pituitary, skeletal muscle, and heart. Journal of Biological Chemistry. 1995;270(11):5691-4.

52. Kane GC, Liu XK, Yamada S, Olson TM, Terzic A. Cardiac KATP channels in health and disease. J Mol Cell Cardiol. 2005;38(6):937-43. Epub 2005/05/25. doi: 10.1016/j.yjmcc.2005.02.026. PubMed PMID: 15910878; PubMed Central PMCID: PMCPMC2736958.

53. Hallermann S, de Kock CP, Stuart GJ, Kole MH. State and location dependence of action potential metabolic cost in cortical pyramidal neurons. Nature neuroscience. 2012;15(7):100714.

54. Howarth C, Gleeson P, Attwell D. Updated energy budgets for neural computation in the neocortex and cerebellum. Journal of Cerebral Blood Flow \& Metabolism. 2012;32(7):1222-32. 
929 55. Hu H, Roth FC, Vandael D, Jonas P. Complementary Tuning of $\mathrm{Na}(+)$ and $\mathrm{K}(+)$ Channel

930 Gating Underlies Fast and Energy-Efficient Action Potentials in GABAergic Interneuron Axons.

931 Neuron. 2018;98(1):156-65 e6. Epub 2018/04/06. doi: 10.1016/j.neuron.2018.02.024. PubMed

932 PMID: 29621485; PubMed Central PMCID: PMCPMC5896255.

933 56. Brown MR, Kaczmarek LK. Potassium channel modulation and auditory processing.

934 Hearing Res. 2011;279(1-2):32-42. Epub 2011/03/19. doi: 10.1016/j.heares.2011.03.004.

935 PubMed PMID: 21414395; PubMed Central PMCID: PMC3137660.

936 57. Crampton WGR. Effects of anoxia on the distribution, respiratory strategies and electric

937 signal diversity of gymnotiform fishes. J Fish Biol. 1998;53(sa):307-30. doi: doi:10.1111/j.1095-

938 8649.1998.tb01034.x.

939 58. Reardon EE, Parisi A, Krahe R, Chapman LJ. Energetic constraints on electric signalling 940 in wave-type weakly electric fishes. J Exp Biol. 2011;214(Pt 24):4141-50. Epub 2011/11/26. doi:

941 10.1242/jeb.059444. PubMed PMID: 22116756.

942 59. Sinnett PM, Markham MR. Food deprivation reduces and leptin increases the amplitude

943 of an active sensory and communication signal in a weakly electric fish. Horm Behav.

944 2015;71:31-40. Epub 2015/04/15. doi: 10.1016/j.yhbeh.2015.03.010. PubMed PMID: 25870018.

945 60. Chen H, Kronengold J, Yan Y, Gazula V-R, Brown MR, Ma L, et al. The N-terminal

946 domain of Slack determines the formation and trafficking of Slick/Slack heteromeric sodium-

947 activated potassium channels. The Journal of Neuroscience. 2009;29(17):5654-65.

948 61. Few WP, Zakon HH. Sex differences in and hormonal regulation of Kv1 potassium

949 channel gene expression in the electric organ: Molecular control of a social signal. Dev

950 Neurobiol. 2007;67(5):535-49. doi: 10.1002/dneu.20305. PubMed PMID: 17443807. 
951 62. Liu H, Wu MM, Zakon HH. A novel Na+ channel splice form contributes to the

952 regulation of an androgen-dependent social signal. J Neurosci. 2008;28(37):9173-82. Epub

953 2008/09/12. doi: 10.1523/JNEUROSCI.2783-08.2008. PubMed PMID: 18784298; PubMed

954 Central PMCID: PMC2615813.

955 63. Liu $\mathrm{H}, \mathrm{Wu}$ MM, Zakon HH. Individual variation and hormonal modulation of a sodium

956 channel beta subunit in the electric organ correlate with variation in a social signal. Dev

957 Neurobiol. 2007;67(10):1289-304. Epub 2007/07/20. doi: 10.1002/dneu.20404. PubMed PMID:

95817638382.

959 64. Marder E, Goaillard J-M. Variability, compensation and homeostasis in neuron and

960 network function. Nat Rev Neurosci. 2006;7(7):563.

961 65. Khorkova O, Golowasch J. Neuromodulators, not activity, control coordinated expression

962 of ionic currents. J Neurosci. 2007;27(32):8709-18. Epub 2007/08/10. doi: 27/32/8709 [pii]

963

964 66. MacLean JN, Zhang Y, Johnson BR, Harris-Warrick RM. Activity-independent

965 homeostasis in rhythmically active neurons. Neuron. 2003;37(1):109-20. Epub 2003/01/16.

966 PubMed PMID: 12526777.

967 67. Santin JM, Schulz DJ. Membrane Voltage Is a Direct Feedback Signal That Influences

968 Correlated Ion Channel Expression in Neurons. Curr Biol. 2019;29(10):1683-8.e2. doi:

$969 \quad 10.1016 /$ j.cub.2019.04.008.

970 68. Howarth C, Gleeson P, Attwell D. Updated energy budgets for neural computation in the

971 neocortex and cerebellum. J Cereb Blood Flow Metab. 2012;32(7):1222-32. Epub 2012/03/22.

972 doi: 10.1038/jcbfm.2012.35. PubMed PMID: 22434069; PubMed Central PMCID:

973 PMC3390818. 
bioRxiv preprint doi: https://doi.org/10.1101/2021.03.08.434486; this version posted March 9, 2021. The copyright holder for this preprint (which was not certified by peer review) is the author/funder, who has granted bioRxiv a license to display the preprint in perpetuity. It is made available under aCC-BY-NC-ND 4.0 International license.

Coregulation of ionic conductances - 61

974 69. Aranda PS, LaJoie DM, Jorcyk CL. Bleach gel: a simple agarose gel for analyzing RNA

975 quality. Electrophoresis. 2012;33(2):366-9.

976 70. Altschul SF, Gish W, Miller W, Myers EW, Lipman DJ. Basic local alignment search

977 tool. Journal of molecular biology. 1990;215(3):403-10.

978 71. Graham BP, Redman SJ. Dynamic Behavior of a Model of the Muscle Stretch Reflex.

979 Neural Networks. 1993;6(7):947-62. PubMed PMID: WOS:A1993MB03000005. 